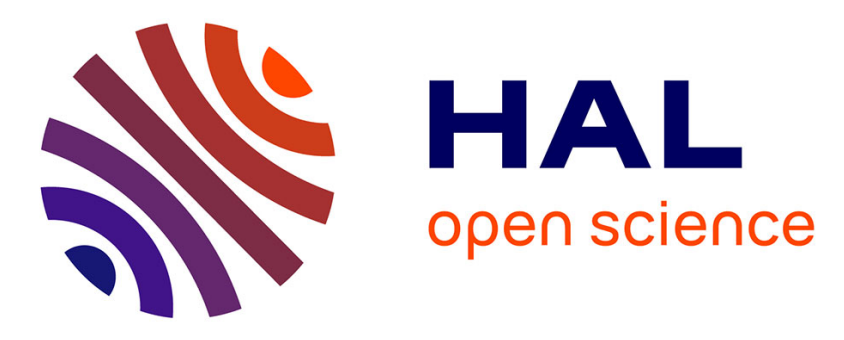

\title{
Geomorphic variability of submarine channelized systems along continental margins: Comparison with fluvial meandering channels
}

Martin Lemay, Jean-Louis Grimaud, Isabelle Cojan, Jacques Rivoirard, Fabien Ors

\section{To cite this version:}

Martin Lemay, Jean-Louis Grimaud, Isabelle Cojan, Jacques Rivoirard, Fabien Ors. Geomorphic variability of submarine channelized systems along continental margins: Comparison with fluvial meandering channels. Marine and Petroleum Geology, 2020, 115, pp.104295. 10.1016/j.marpetgeo.2020.104295 . hal-02482269

\section{HAL Id: hal-02482269 \\ https://hal.science/hal-02482269}

Submitted on 4 May 2020

HAL is a multi-disciplinary open access archive for the deposit and dissemination of scientific research documents, whether they are published or not. The documents may come from teaching and research institutions in France or abroad, or from public or private research centers.
L'archive ouverte pluridisciplinaire HAL, est destinée au dépôt et à la diffusion de documents scientifiques de niveau recherche, publiés ou non, émanant des établissements d'enseignement et de recherche français ou étrangers, des laboratoires publics ou privés. 


\section{Geomorphic variability of submarine} channelized systems along continental margins: comparison with fluvial meandering channels

\section{Martin Lemay ${ }^{1,2 *}$, Jean-Louis Grimaud ${ }^{1}$, Isabelle Cojan ${ }^{1}$, Jacques}

Rivoirard ${ }^{1}$, Fabien Ors ${ }^{1}$

1 MINES ParisTech - PSL University, Centre de Géosciences, 35 rue St Honoré, 77300 Fontainebleau, France

${ }^{2}$ now at IFP Energies nouvelles, 1 et 4 avenue de Bois-Préau, 92852 Rueil-Malmaison Cedex - France.

Corresponding author: martin.lemay@mines-paris.org

Highlights

- New geomorphic classification applied worldwide to modern submarine channelized systems

- Flow conduit geometry changes according to their location along continental margins

- Submarine unit leveed channels are the most analogous to alluvial meandering rivers

- Submarine leveed channel width and area correlate with slope similarly to rivers

- Increasing aspect ratio down-slope is likely related to flow deconfinement 

5

\section{Abstract}

Understanding submarine sediment conduits is a challenging yet rewarding task given its applications in offshore industries and source-to-sink studies. Despite flow structure dissimilarities, sinuous submarine sediment conduits display morphologies similar to alluvial meandering rivers. An extensive quantification of degrees of (dis)similarity is however lacking. This study combines (i) a new geomorphic classification of submarine sediment conduits relying on cross-sectional data only, complemented by (ii) measurements of planform (sinuosity, wavelength, amplitude) and cross-sectional (bankfull width, depth, section area) parameters to compare alluvial meandering and submarine systems. We apply the methods to a worldwide dataset including 254 measurements from 35 modern systems. We identify four types of submarine sediment conduits including composite (i.e., canyon and valley) and unit (i.e., incised or leveed channel) types. The following findings arise. (i) Submarine sediment conduit geomorphology is strongly controlled by slope, mostly depending on location along the continental margin. Composite and erosive submarine sediment conduits are located on the continental slope and unit and constructive channels extend down to the basin floor. (ii) Submarine unit leveed channels form a consistent group of constructive, higher-order, smaller-size and more laterally mobile submarine sediment conduits. (iii) Submarine unit leveed channels are the most analogous to alluvial meandering rivers. (iv) Without discharge contribution from tributaries, the width and the area of long-running submarine sediment conduits increase as they migrate towards the abyssal plains. Such behavior is similar to rivers, although it is better explained for submarine sediment conduits by progressive flow deconfinement, and decreasing bank cohesion and friction angle.

\section{Keywords}

Submarine systems; Channel morphometrics; Geomorphology; Turbidity flow; Meandering process 


\section{Introduction}

Submarine channelized systems are the final links of the source-to-sink sediment transfer chain (Allen, 2017), which extend over the entire submarine environment from the shelf to the abyssal plain (Figure 1 - Deptuck et al., 2007; Wynn et al., 2007). The interest in these channelized systems is constantly growing because they transfer sediment, organic carbon, nutrients and contaminants to the deep sea (Galy et al., 2007; Hugues et al., 2015; Kane and Clare, 2019), create large hydrocarbon reservoirs (Weimer and Slatt, 2004), and may impact offshore facilities such as hydrocarbon production platforms, pipelines, telecommunication cables, wind power plants, or -in the near future- deep water mining apparatuses (Baker et al., 2016). One aim is therefore to understand the dynamics of these systems to improve their modeling.

Despite recent progress on in-situ flow measurements (Paull et al., 2018), our understanding of the long-term $\left(10^{2}-10^{4} \mathrm{yr}\right)$ evolution of submarine sediment conduits and associated deposits is still incomplete (Mulder and Alexander, 2001; de Leeuw et al, 2018; Ono and Plink-Björklund, 2018). Due to the difficulty of monitoring submarine sediment conduit evolution, a common approach is to formulate theories based on those describing fluvial channel morphodynamic processes. Physical processes at play at the scale of the full turbidity current profile are incontestably different from that of rivers (Wynn et al., 2007 and references therein), for example owing to the role of sediments as flow driver (Parker et al. 1986; Konsoer et al., 2013; Traer et al., 2018), flow stratification (Dorrell et al., 2014; Luchi et al., 2018), friction at flow upper interface (Konsoer et al., 2013), water entrainment (Ellison and Turner, 1959; Pirmez and Imran, 2003; Traer et al., 2018), flow overspill and stripping (Peakall et al., 2000; Traer et al., 2018), or variations in secondary currents (Azpiroz-Zabala et al., 2017; Dorrell et al., 2018). However, similarities of planform morphology and other geomorphic features (Peakall et al., 2000; Wynn et al 2007 and references therein; Konsoer et al., 2013) suggest that concepts that apply to rivers, such as styles of channel migration and channel-forming flows, apply to submarine channels too. Indeed, both fluvial and submarine sediment conduits display braid bars (Hesse et al., 2001; O'Cofaigh et al., 2006; Foreman et al., 2015), lateral 
accretion packages (Abreu et al., 2003), bend cutoffs, levees or crevasse splays (Figure 1 - Posamentier, 2003; Wynn et al., 2007). Applying fluvial theories to submarine systems allows to better understand the processes at play in the latter -e.g., the larger size of submarine sediment conduits compared to river channels due to the lower density contrast between the current and the ambient fluid (Konsoer et al., 2013; Limaye et al., 2018; Shumaker et al., 2018), the braiding-sinuous threshold (Foreman et al., 2015) or the channel mobility number (Jobe et al., 2016).

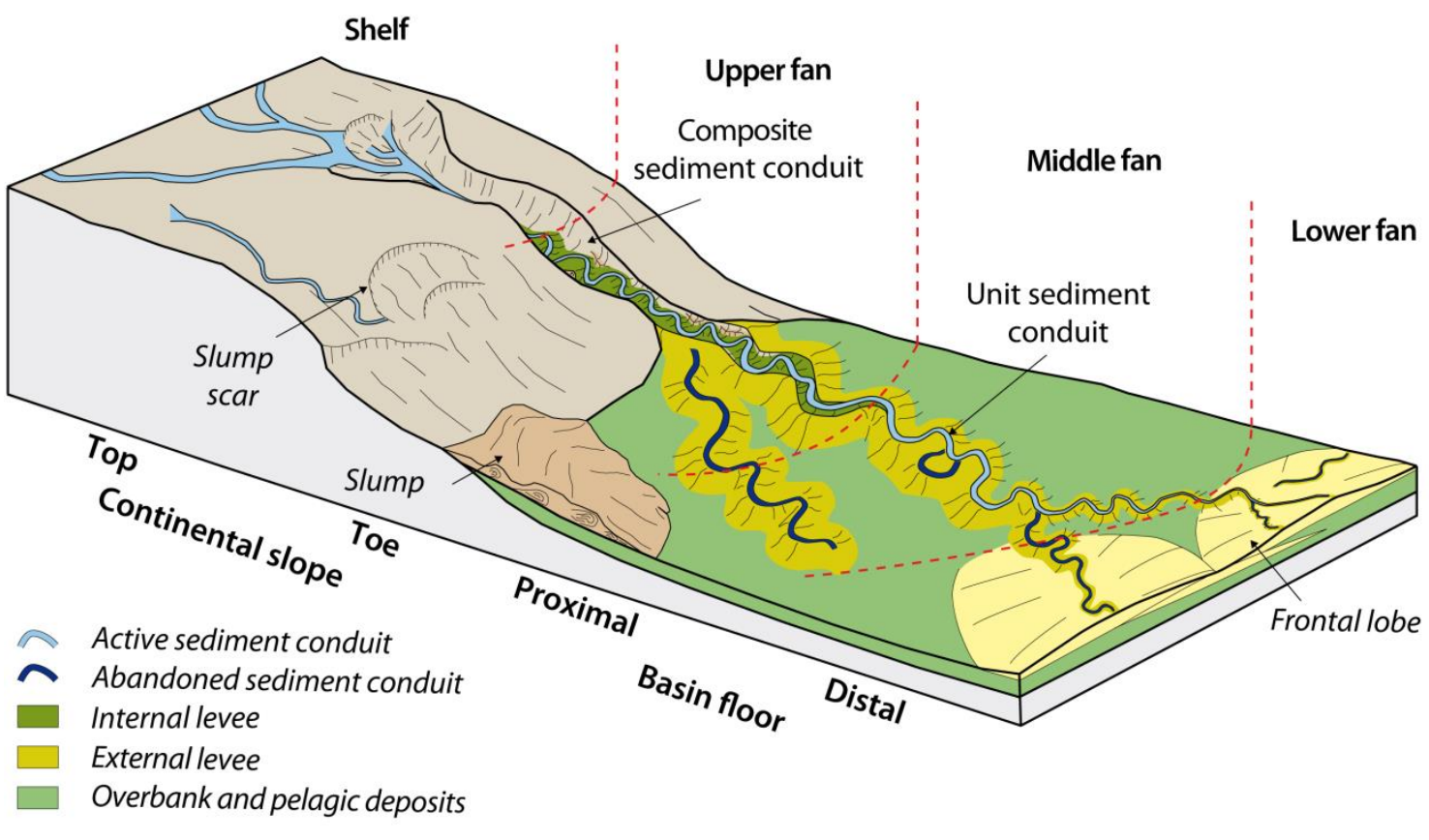

Figure 1: Channelized submarine systems with the submarine environment subdivision used in this study.

In fluvial systems, seminal studies showed that channel planform morphology (sinuosity, wavelength, amplitude) and cross-sectional geometry (bankfull width, depth, area) parameters (Jefferson, 1902; Friedkin, 1945; Leopold and Wolman, 1960; Williams, 1986; Bridge and Mackey, 1993) are correlated to each other and to channel slope and river dynamics (e.g., flow or sediment discharge) according to power laws (Table 2; Leopold and Maddock 1953; Leopold and Wolman, 1957; Williams, 1986; Held, 2011). The derived equations are valuable in many practical applications such as hydraulic engineering and restoration projects (e.g., Kondolf, 2016 and references therein), paleo-hydrologic studies (Williams, 1978, 1986; Bridge, 2003 and references therein; Held, 2011), or reservoir modeling (Bridge and Mackey, 1993; Heller and Paola, 1996; Tye, 2004; Lopez et al., 2008; Pyrcz et al., 2015; Parquer et al., 2017). Establishing 
similar relationships for submarine channelized systems would be equally promising and could generate insight into the (dis-)similarities with fluvial channels in terms of processes. Accurately comparing rivers and submarine sediment conduits is however still a challenge for three reasons: (i) existing datasets of submarine sediment conduits are based on a limited number of systems compared to riverine datasets, (ii) the measurement methodology used for submarine sediment conduits slightly varies from the one used for rivers (Pirmez and Imran, 2003; Clark and Pickering, 1996; Konsoer et al., 2013) and finally (iii) current submarine nomenclatures do not take into account the downstream evolution of the formative processes and the shape of submarine sediment conduits (Figure 1 - Babonneau et al., 2002). The accuracy of the comparisons between submarine sediment conduits and rivers is therefore affected by these issues (Clark and Pickering, 1996; Pirmez and Imran, 2003; Wynn et al., 2007; Konsoer et al., 2013).

In this study, we introduce a new geomorphic classification of modern submarine sediment conduits. We then make a comparison between the different submarine sediment conduits types and alluvial sinuous channels based on geometric parameters. This methodology is applied to a worldwide dataset of the morphology of submarine sediment conduits based on published data, which is the most extensive to our knowledge. We show that the location along the continental margin has a first-order control on the flow conduit morphometry. Based on the geometric parameters, we find that submarine leveed channels are very similar to alluvial meandering rivers in terms of parameter scaling, which allows us to infer submarine flow processes.

\section{Material and methods}

\subsection{Submarine sediment conduit geomorphic classification}

Existing submarine sediment conduit nomenclatures vary according to the field of study -i.e. geomorphology, stratigraphy, process sedimentology- and authors (Clark and Pickering, 1996; Wynn et al., 2007). This makes the dialogue between communities sometimes difficult. For example, the term 
"sediment conduit" is employed as a generic term (e.g., Graham and Bachman, 1983; Carter and Carter, 113 1987; Clark and Pickering, 1996; Deptuck et al., 2007; Wiles et al., 2017; Harishidayat et al., 2018; Traer et 114 al., 2018), but many authors interchangeably used "canyon" (Heezen et al., 1959; Huvenne et al., 2014), 115 "valley" (e.g., Shepard, 1965; Normark et al., 1993; Curray et al., 2003), or "channel" (Normark et al., 1993; Pirmez and Imran, 2003; Wynn et al., 2007; Konsoer et al., 2013). Modern conduits can primarily be 117 classified on the basis of their location of occurrence in the system (i.e., canyons connecting the shelf to the continental slope, valleys on the toe of the continental slope, and channels downstream in the basin; Shepard, 1965; Normark et al., 1993; Babonneau et al., 2002). Such distinction is however somewhat incomplete as it does not consider local adjustment to, for example, slope and/or lithological change along continental margins. Other features are thus used -and must be combined- to identify precisely sediment conduit types. Canyons consist in deeply erosive V-shapes with steep walls, steep gradient, and showing a limited development of external levees (Shepard, 1965; Normark et al., 1993; Wynn et al., 2007; Hansen et al., 2015; Harishidayat et al, 2018). Valleys and channels are smaller than canyons, located on more gentle slopes, associated with external and/or internal levees or terraces, and have a sinuous thalweg (Normark et al., 1993; Babonneau et al., 2002; Wynn et al., 2007; Hansen et al., 2017). In stratigraphic studies, large valleys (also called channel complexes or channel-belts) are differentiated from higher-order and smaller channels or channel fill deposits (Mayall et al., 2006; Deptuck et al., 2007; Hodgson et al., 2011; Janocko et al., 2013b; Covault et al., 2016). Process-oriented studies consider that submarine channels are created from flow processes somehow analogous to those of continental rivers (Peakall et al., 2000; Kneller, 2003; Pirmez and Imran, 2003; Konsoer et al., 2013), while valleys are shaped by supplementary processes including channel entrenchment, lateral migration and aggradation (Babonneau et al., 2004; Deptuck et al., 2007). conduits allowing for a clear and objective definition of canyons, valleys and channels (Figure 2). The first criterion is the occurrence or absence of levees flanking the submarine sediment conduit (along one or both sides). Levees are constructional wedges that thin away from the sediment conduit (Skene et al., 
2002; Kane and Hodgson, 2011). The second criterion is the presence or absence of terraces and/or internal levees (Kane and Hodgson, 2011) within the considered conduit delimiting an "entrenched submarine sediment conduit" -i.e., of smaller size (Figures 2 and 3a). When these internal features are present the sediment conduit is termed composite, otherwise it is termed unit. Note that the entrenched conduit in a composite sediment conduit is often unit but not necessarily.

The two criteria described above enable the identification of two common composite submarine sediment conduits (here termed constructive valleys -i.e., with flanking external levees- and incising canyons -i.e., no external levees), and two unit submarine sediment conduits (leveed and incised channels - Figure 2). Note that these criteria apply locally, hence a given submarine sediment conduit may change in type along its course. For instance, in the Congo fan (Babonneau et al., 2002) it may be a canyon on the continental slope, split into several valleys downstream when external levees appear, and finally transition into unit leveed channels on the basin floor when internal levees and/or terraces disappear (Figure 1).

SUBMARINE SEDIMENT CONDUIT (SC)

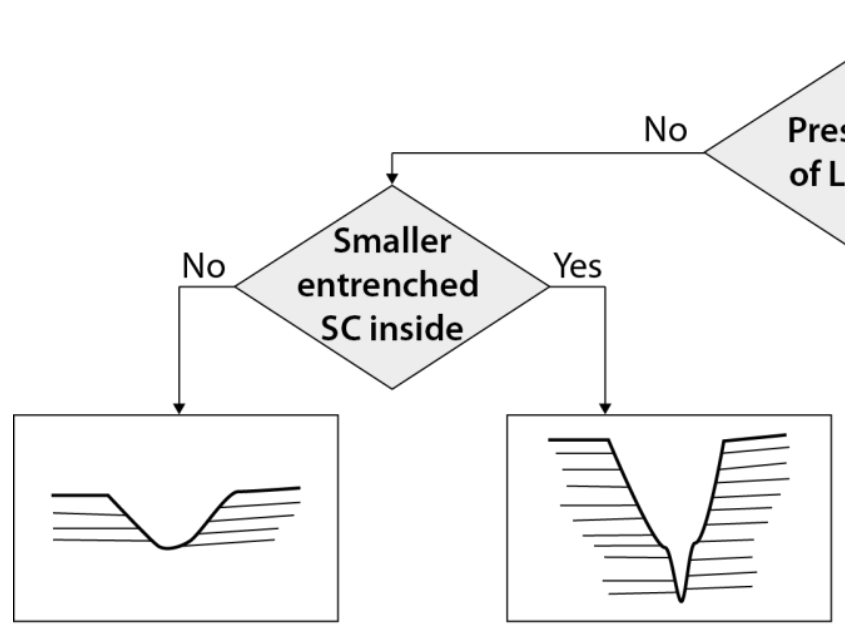

Unit
Composite

CANYON

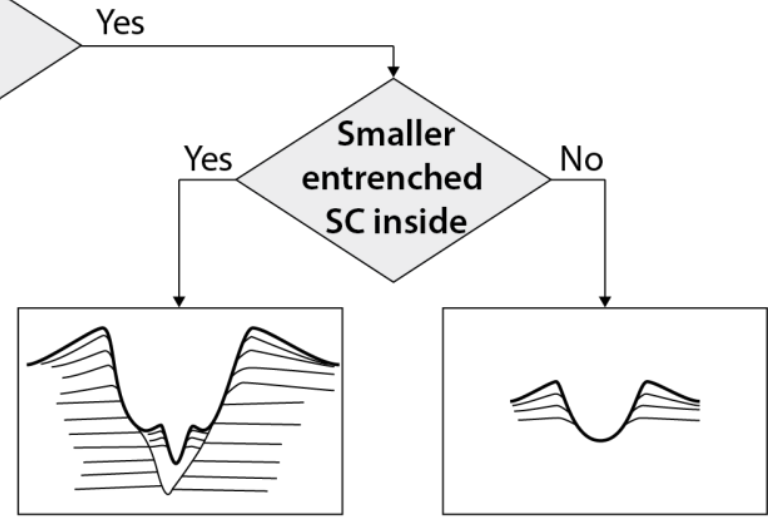

Composite

VALLEY
Unit

LEVEED CHANNEL

Figure 2: Classification of the submarine sediment conduits based on the presence of flanking levees and their composite nature.

\subsection{Measurement of the geometric parameters}


Submarine sediment conduits were characterized using the metrics defined for alluvial sinuous

rivers (Leopold and Wolman, 1960; Williams, 1986; Sauer and Turnipseed, 2010), allowing for direct comparison with fluvial data. Local longitudinal conduit bed slope, planform and cross-sectional parameters were measured on published images when available. The measurements were performed at specific locations along the conduit course; thus a given channelized system may be characterized by one or several (average 3; maximum 33) measurement points. Some submarine systems such as the Congo or the Amazon are slightly over-represented due to the large amount of data available. Depending on the quality of the data, all parameters may not be available for a given measurement point.

Cross-sectional parameters are width $(W)$, mean $\left(H_{\text {mean }}\right)$ and maximum $\left(H_{\max }\right)$ depths, and area. In fluvial systems, these parameters are measured at the bankfull stage -i.e., the maximum discharge that a river channel can contain before overbank flooding- and correspond to river channel dimensions (Leopold and Wolman, 1957; Bridge, 2003). Similarly, we selected published submarine sediment conduit crosssections perpendicular or slightly oblique to straight reaches (e.g., around the inflection zone, see hereafter) (Figure 3) that show a well-defined geometry. Sediment conduit floor and banks were first digitized. The top of channel banks correspond to the slope break observed at the top of levees (when present) or along the substrate (Figure 3a). The amount of picked points was between 15 and 50 depending on the resolution of data and the complexity of the submarine sediment conduit shape as illustrated in Figure 3. Based on the similarity with the bankfull width in fluvial systems (Williams, 1978; Sweet and Geratz 2003), the submarine sediment conduit width was defined as the horizontal distance between the two upper points of the bank (Figure 3b and 3c). Due to levee asymmetry (Peakall et al., 2000; Straub et al., 2008), the maximum depth of submarine sediment conduits was defined as the vertical distance between the lower point of the contour and the mean elevation of the upper banks (Babonneau et al., 2002; Konsoer et al., 2013). The submarine sediment conduit cross-sectional area was defined as the area comprised within the floor of the submarine sediment conduit and the line that connects the highest points of the two banks. Finally, the submarine sediment conduit mean depth was computed as the ratio of the cross-sectional area to the bankfull width (Leopold and Maddock, 1953). 


\section{a Seismic cross-section}

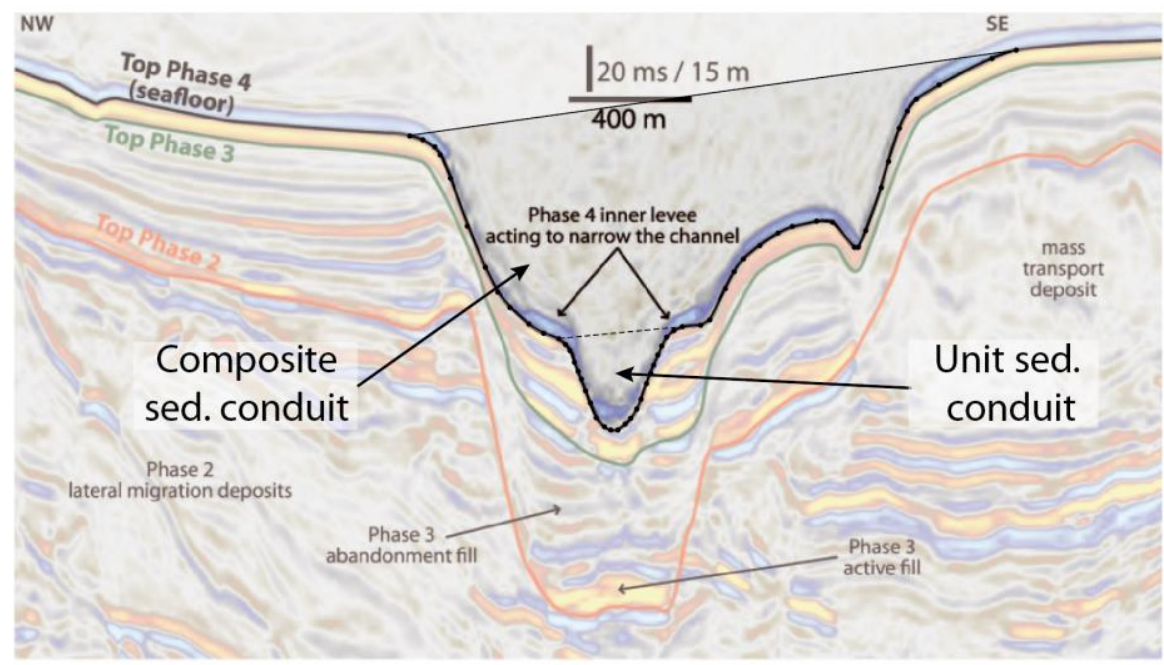

b Composite sediment conduit W

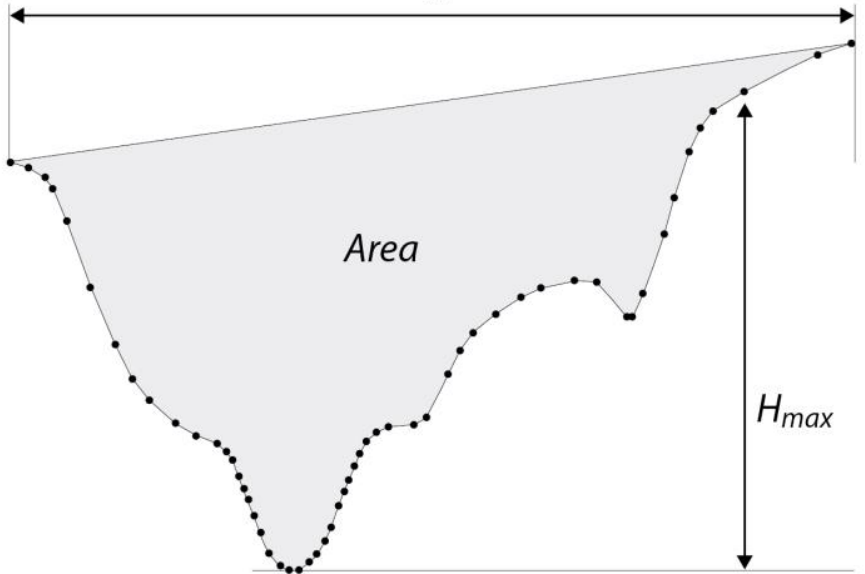

c Unit sediment conduit

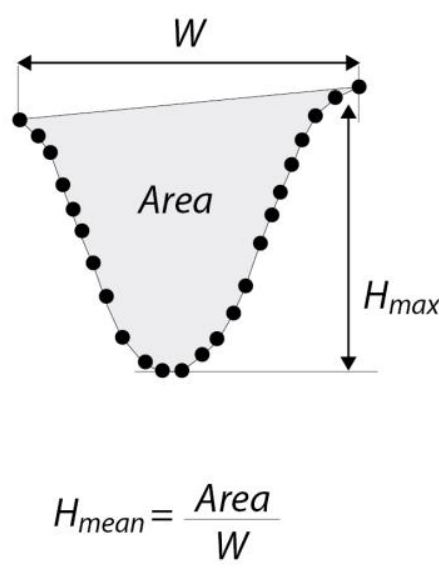

Figure 3: Cross-sectional measurement methodology. Interpreted seismic line (from Jobe et al., 2016) showing a composite and an entrenched unit submarine sediment conduit (a). Definition of the bankfull width $(W)$, maximum $\left(H_{\max }\right)$ and mean $\left(H_{\text {mean }}\right)$ bankfull depths, and the cross-sectional area for the composite (b) and unit (c) submarine sediment conduits.

Bed slope corresponds to the first derivative of bed elevation profile and was measured along conduits close to the location of cross-sections from published elevation profiles (Figure 4). Regional slope corresponds to the slope along the mean flow direction and is related to bed slope through conduit sinuosity. Selected planform sediment conduit parameters were sinuosity (Allen, 1984), meander wavelength $(\lambda)$ and amplitude $(A)$ (Leopold and Wolman, 1960). For a given measurement point, the sinuosity -i.e., the ratio between the curvilinear distance along the studied reach and the sum of the 
lengths of the segments linking inflection points (Allen, 1984)- was computed over a window equal to 20

193 times the sediment conduit width (10 times on either side away from the cross-section) allowing the 194 sampling of several meanders. The same window was used to compute meander wavelength and amplitude following the algorithm developed by Sylvester and Pirmez (2017): (i) centerline points were first resampled every $50 \mathrm{~m}$ based on a parametric spline function; (ii) the centerline was smoothed using a Savitzky-Golay filter (Savitzky and Golay, 1964) with a third-order polynomial and a window length scale approximately equal to half the meander wavelength; (iii) the curvatures were computed and smoothed using the same filter; (iv) inflection points and apexes defined as null and maximum curvature points respectively are determined from the smoothed centerline; finally $(\mathrm{v})$ the previously mentioned planform parameters were computed, discarding wavelength and amplitude of straight channel segments (i.e., with less than 1.01 bend sinuosity; Sylvester and Pirmez, 2017). The wavelength of a given meander is the length of the segment joining the apex of each neighboring bend (Figure 4). Meander amplitude is the length of the segment perpendicular to the previous segment and joining the apex of the given meander. This value is twice the "amplitude" of a wave as defined in physics. Note that steps ii to v were repeated until the wavelength converged. Meander wavelength and amplitude were averaged using the same window used for obtaining the sinuosity.

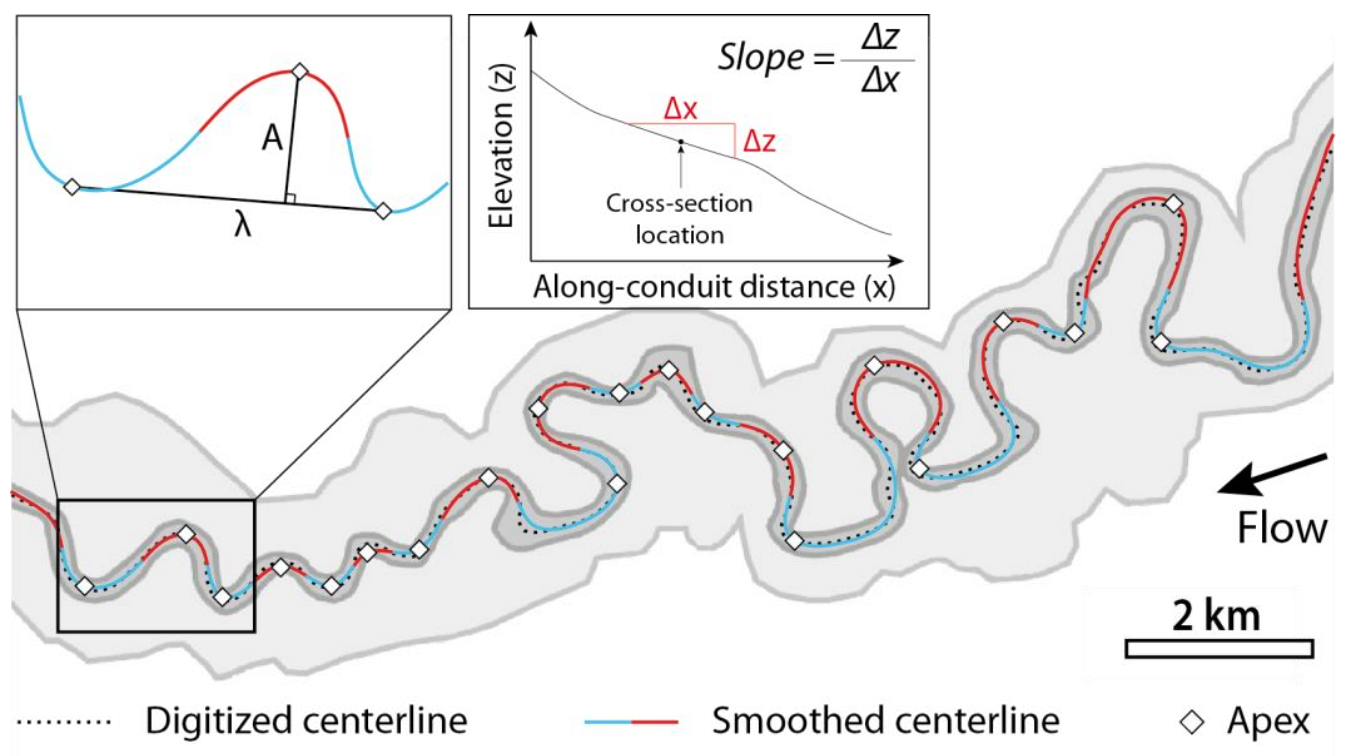


Figure 4: Planform geometry measurements. A: meander amplitude, $\lambda$ : meander wavelength. Submarine sediment conduits example is from the Benin major system (Deptuck et al., 2007). Conduit bed slope is measured along channel centerline while regional slope is measured along the flow direction.

\subsection{Statistical analysis}

The distributions of morphometric parameters were displayed using box plots for each sediment conduit type. Additional variance analyses were performed to test if parameters distributions significantly differed between conduit types. The non-parametric one-way Kruskal-Wallis test (Kruskal and Wallis, 1952) was selected based on the non-normality of our data and the reduced number of observations for some parameters. When Kruskal-Wallis tests revealed statistically different conduit types, a post-hoc group pairwise comparison was carried out using the Dunn's method (Dunn, 1964). This method accounts for unequal sample sizes. Conduit types were considered as significantly different when the returned $p$-value was lower than 0.05 (Table 1).

The relationships between morphometric parameters -i.e., meander wavelength, amplitude, width, and mean bankfull depth- were computed for all submarine sediment conduits together and also separately for leveed channels. Least-square linear regressions were performed on log-transformed data, resulting in power-law equations. The equation, regression curves and associated $95 \%$ confidence intervals for the mean prediction were displayed only when the $p$-value was lower than 0.05 -rejecting the noncorrelation hypothesis- and/or the coefficient of determination $R^{2}$ was higher than 0.1 .

The obtained submarine sediment conduit morphometric relationships were compared first to each other and then to existing relationships for fluvial channels (Table 2). As an illustration, we plotted fluvial data from Held's (2011) database (i.e., 193 measures from 136 alluvial rivers in humid climate regions in both the United States and Australia) for cross-section parameters, that we extended for planform parameters using satellite pictures on large alluvial meandering river systems (Figures 10 and 11). 
Submarine sediment conduits were measured using more than 60 publications to obtain 254

234 measurements (each measurement being therefore composed at least of the 4 cross-sectional parameters)

235 from 35 modern submarine channelized systems (Figure 5a; see Supplementary Materials). These data 236 come from seafloor Digital Elevation Models, shallow seismic and sonar surveys with vertical resolutions 237 varying from few to tens of meters depending on the year of acquisition and the water depth of sediment 238 conduits (e.g., Clark and Pickering, 1996; Wynn et al., 2007). Hence, despite our carefulness, data contain 239 uncertainties; but this is inherent in the study of large datasets and should not preclude the identification 240 of major trends.

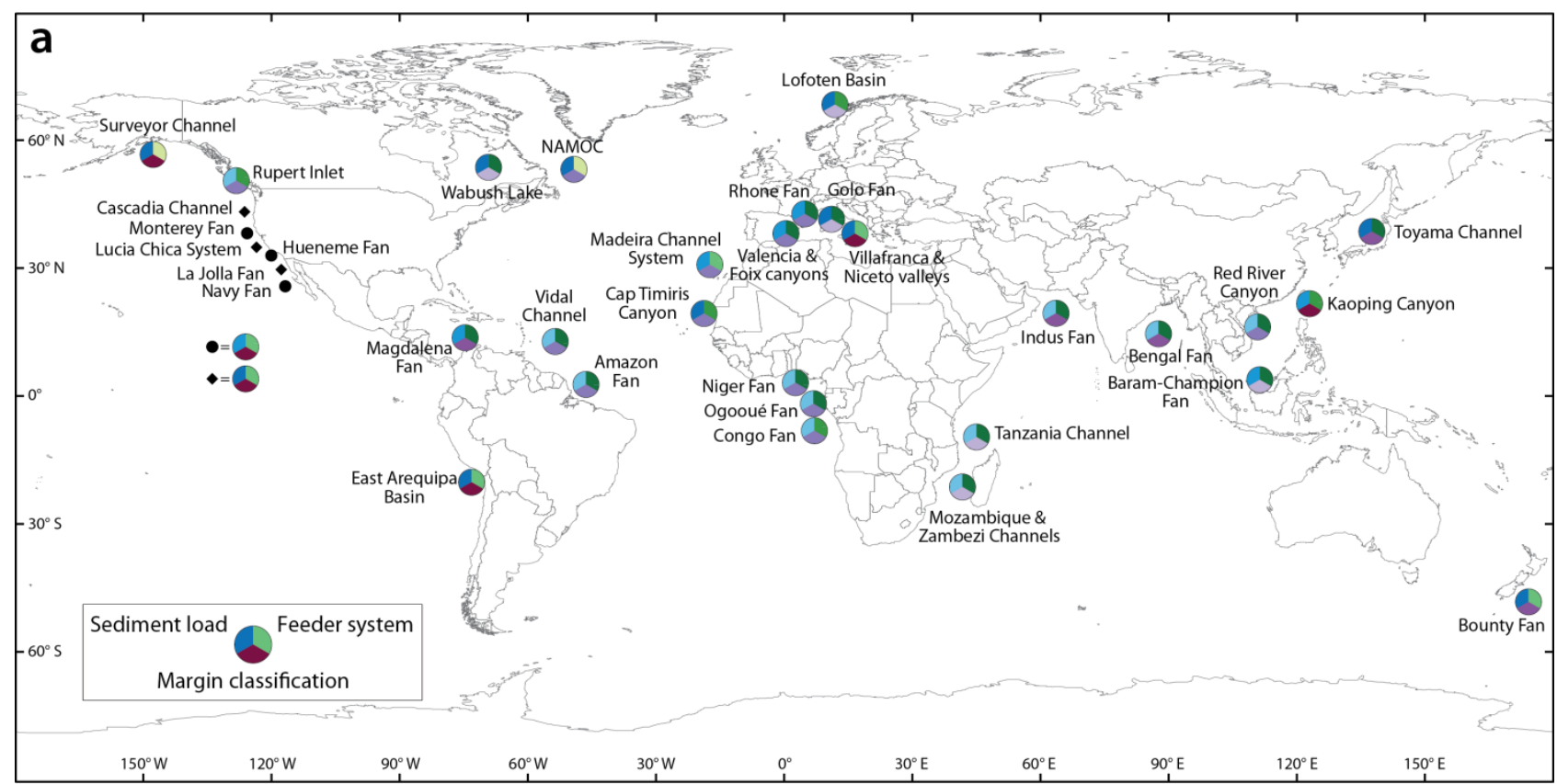

\section{b Margin classification Feeder system}
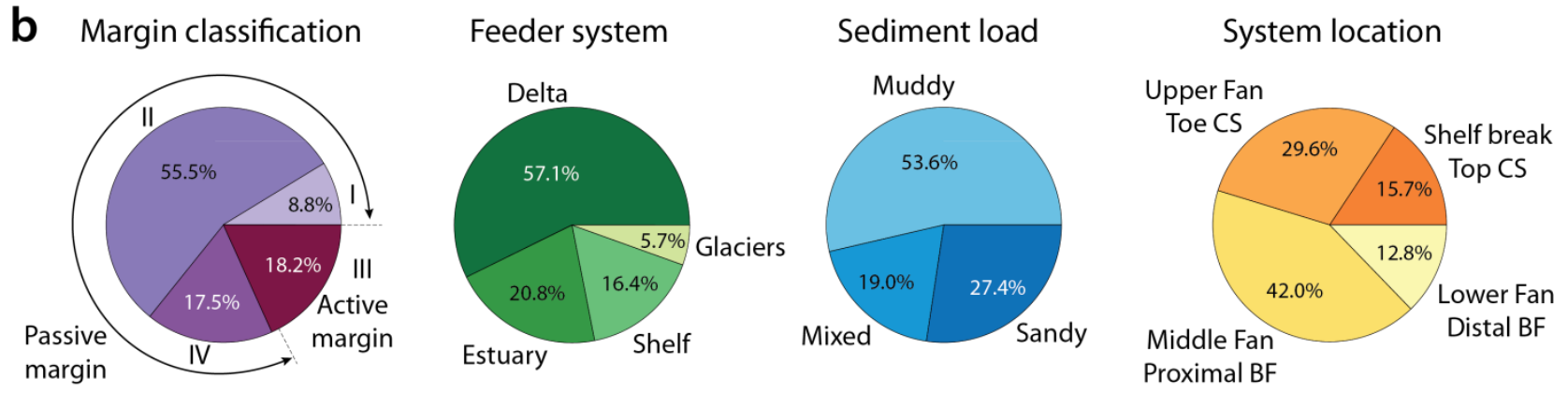

Figure 5: Location of sampled submarine systems (a). Distribution of submarine systems according to: margin classification (Wetzel, 1993), feeder system, sediment load and system location (b). Colors in circles in (a) correspond to the first three systems characteristics shown in (b). I: immature passive margin, II: mature passive margin, III: active margin, IV: passive margin with active hinterland, CS: continental slope, BF: basin floor. 
Special attention was paid to include submarine systems from a large range of latitudes (from $-45^{\circ}$

249 for the Bounty fan to $+65^{\circ}$ for the Lofoten basin), or tectonic settings ( $18.2 \%$ from active margins and $81.8 \%$ 250 from passive margins of different types according to the classification of Wetzel (1993); Figure 5). The 251 studied systems comprise very large to medium size submarine systems such as the Indus or the 252 Magdalena fans, and small ones like the Golo fan or the Rupert Inlet system. The systems are fed by a wide 253 range of sediment sources with varied mechanisms initiating the flows, i.e., deltas (57.1\%), estuaries 254 (20.8\%; e.g., Congo fan), directly from the shelf (16.4\%; e.g., Navy fan), and glaciers (5.7\%; i.e., NAMOC and 255 Surveyor Channel). The sediment load varies from muddy (53.6\%; e.g., Amazon or Mississippi fans), to sandy (27.4\%; e.g., La Jolla fan or the Cascadia system) and mixed (19.0\%; e.g., Rhone or Nile fans) (Figure 5b), according to the classification of Reading and Richards (1994). The majority of the sampled submarine sediment conduits comes from submarine fans (58.3\%) but $41.7 \%$ represent isolated submarine sediment conduits such as NAMOC or the Tanzania Channel. Four marine environments are represented, based on their location relative to the continental slope: (i) the top of the continental slope, (ii) the toe of the continental slope (or upper fan), (iii) the proximal basin floor (usually middle fan), and (iv) the distal basin floor (or lower fan) (Figures 1 and $5 b$ ). This submarine environment zonation applies to both turbidite fans and isolated submarine sediment conduits.

\section{Results}

\subsection{Geomorphic control on the distribution of sediment conduit data}

The dataset encompasses a wide range of geological and geomorphic settings over four submarine domains (i.e., top and toe of the continental slope, proximal and distal basin; Figures 5 and 6). The dataset also covers median regional slopes ranging from $2.1 \%$ (top of continental slope) to $0.4 \%$ (distal basin floor). Most features are unit submarine sediment conduits (81.1\%), of which $63.4 \%$ are leveed channels ( $n=161$ ) and $17.7 \%$ are incised channels $(n=45)$. Composite submarine sediment conduits $(n=48)$ are divided into 
canyons (6.3\%) and valleys (12.6\%). Submarine sediment conduits are mainly located at the toe of 272 continental slope (25.2\%) and within proximal basin floor $(44.5 \%)$. The remaining submarine sediment 273 conduits (30.3\%) are evenly distributed between the top of the continental slope $(16.5 \%)$ and the distal basin floor (13.8\%).

The distribution of submarine sediment conduits strongly depends on their location within the submarine system (Figure 6). The upstream part of the continental slope is dominated by incised sediment conduits of which $33.3 \%$ are classified as incised channels and $23.8 \%$ as canyons, while leveed channels and valleys represent $40.5 \%$ and $2.4 \%$ of the conduits respectively. The toe of the continental slope is dominated by valleys (43.8\%), followed by leveed channels $(29.7 \%)$ and incised channels (17.2\%). The remaining sediment conduits correspond to canyons (9.3\%). Going downslope, except for 3 valleys the great majority of sediment conduits are unit channels, with an overrepresentation of leveed channels (i.e., increasing from $82.3 \%$ in the proximal plain to $91.4 \%$ in the distal plain).

\section{a. Submarine domain}

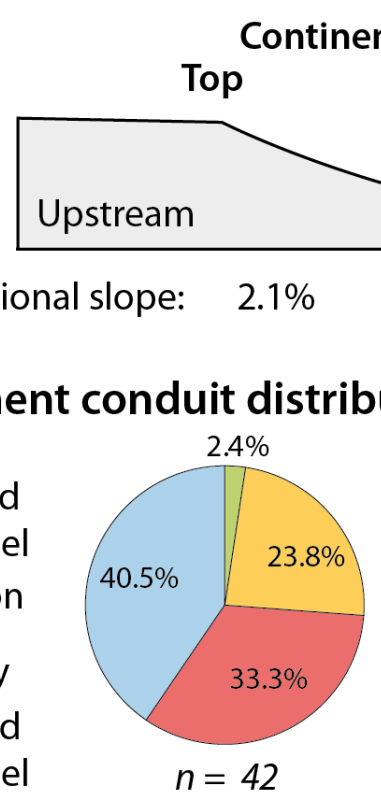

\section{b. Sediment conduit distribution per submarine domain}

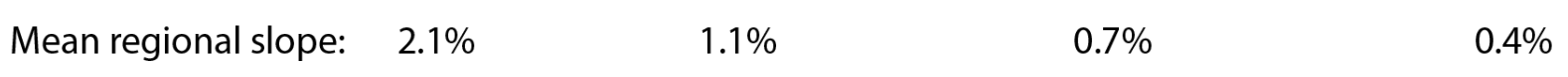

284 Figure 6: Distribution of submarine sediment conduit types in the submarine environment. Regional slope evolution along submarine domains from the continental slope to the basin floor (a), and associated domain). 


\subsection{Geometry of submarine sediment conduits}

The different submarine sediment conduit types (i.e., incised channel, canyon, valley, leveed

channel) can be distinguished according to their geometry (i.e., bed slope, sinuosity, meander wavelength

and amplitude, area, bankfull width, mean and maximum bankfull depths) as shown by the statistical

are presented following the classification scheme (Figure 2).

Table 1: Results of the non-parametric analysis of variance on morphometric parameters*

\begin{tabular}{|c|c|c|c|c|c|c|}
\hline Morphometric parameter & Kruskal-Wallis & Dunn's & st-ho & airwise co & parison & -value) \\
\hline & & & IC ${ }^{1}$ & Canyon & Valley & $\mathrm{LC}^{2}$ \\
\hline & & IC & & 0.025 & 1.0 & $2.210^{-8}$ \\
\hline Area & 1.210 & Canyon & & & 0.018 & $1.910^{-11}$ \\
\hline & & Valley & & & & $1.210^{-5}$ \\
\hline & & & IC & Canyon & Valley & LC \\
\hline & & IC & & $4.710^{-3}$ & 1.0 & $9.510^{-5}$ \\
\hline Wiatn & $3.510=$ & Canyon & & & 0.046 & $4.710^{-7}$ \\
\hline & & Valley & & & & $2.710^{-5}$ \\
\hline & & & IC & Canyon & Valley & LC \\
\hline Moan Denth & $110^{-17}$ & IC & & 0.27 & 0.70 & $2.410^{-10}$ \\
\hline IViean Deptn & $4.110^{-1}$ & Canyon & & & 0.012 & $5.910^{-10}$ \\
\hline & & Valley & & & & $6.410^{-4}$ \\
\hline & & & IC & Canyon & Valley & LC \\
\hline & {$\left[0.0^{-19}\right.$} & IC & & 0.26 & 1.0 & $2.710^{-11}$ \\
\hline Traximum Deptn & $3.910=$ & Canyon & & & 0.020 & $1.410^{-10}$ \\
\hline & & Valley & & & & $5.910^{-5}$ \\
\hline Wavelength & 0.29 & & & - & & \\
\hline Amplitude & 0.09 & & & - & & \\
\hline Bed_slope & 0.044 & $p-v o$ & $>0.0$ & r all pairy & e compa & sons \\
\hline Sinuosity & 0.81 & & & - & & \\
\hline & & & IC & Canyon & Valley & LC \\
\hline Denth ratio & $1210^{-6}$ & IC & & 0.89 & 1.0 & $5.310^{-3}$ \\
\hline Deptir iacio & 1.210 & Canyon & & & 1.0 & $1.110^{-3}$ \\
\hline & & Valley & & & & $9.410^{-4}$ \\
\hline & & & IC & Canyon & Valley & LC \\
\hline & & IC & & 0.64 & $6.110^{-3}$ & 0.18 \\
\hline (3) & 0.011 & Canyon & & & 1.0 & 1.0 \\
\hline & & Valley & & & & 0.24 \\
\hline Wavelength/Amplitude & 0.36 & & & - & & \\
\hline & & & IC & Canyon & Valley & LC \\
\hline Wavelength/Width & $20^{-6}$ & IC & & 0.021 & 1.0 & 0.046 \\
\hline 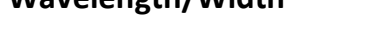 & 4.210 & Canyon & & & 0.058 & $1.110^{-5}$ \\
\hline & & Valley & & & & 0.45 \\
\hline
\end{tabular}




\section{Amplitude/Width}

$3.510^{-7}$

\begin{tabular}{|c|c|c|c|c|}
\hline & IC & Canyon & Valley & LC \\
\hline IC & & 0.020 & 1.0 & $7.610^{-3}$ \\
\hline Canyon & & & 0.013 & $1.910^{-6}$ \\
\hline Valley & & & & 0.82 \\
\hline
\end{tabular}

* In green are the results that support significant differences between submarine conduit types (i.e., $p$ value $<0.05) .{ }^{1}$ Incised channels; ${ }^{2}$ Leveed channels

\subsubsection{Submarine sediment conduit slope and dimensions}

Along-conduit bed slope and planform morphometric parameters (i.e., sinuosity, wavelength, and amplitude) do not show significant differences according to submarine sediment conduit types (Table 1) although the Kruskal-Wallis test results in a $p$-value slightly lower than 0.05 for bed slope. Bed slope values range from 0.01 to $3.7 \%$ with an average slope around $0.8 \%$ (Figure $7 a$ ). The mean sinuosity varies from 1.15 to 1.28 and maximal values are up to 2.2 (Figure $7 \mathrm{~b}$ ). The wavelength of submarine meanders is on average $10-30 \mathrm{~km}$ and spans two orders of magnitude. Meander amplitude is around five times lower than the wavelength with average values around $1-7 \mathrm{~km}$.
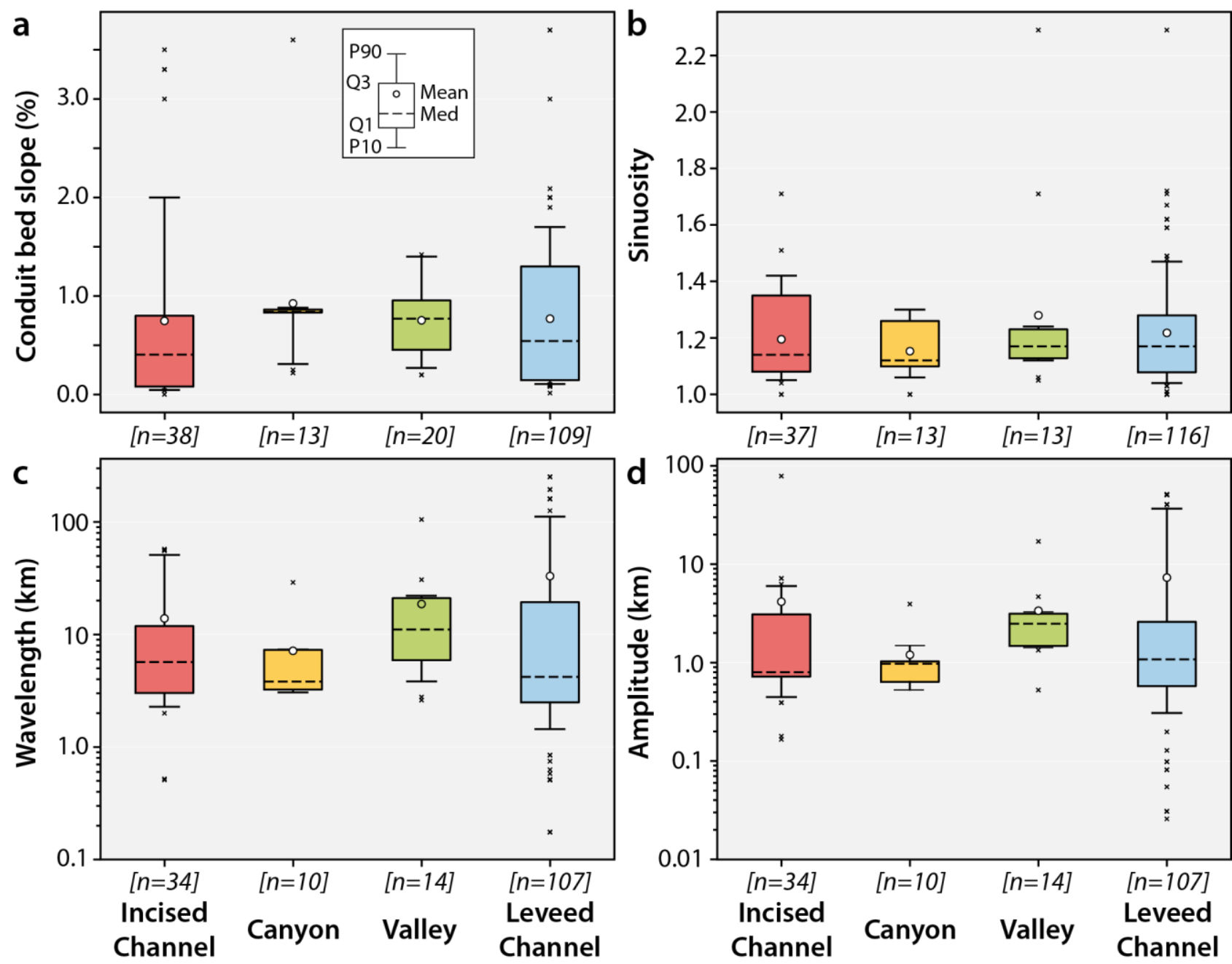
Figure 7: Submarine sediment conduit morphology: along-conduit bed slope (a), sinuosity (b), meander wavelength (c) and amplitude (d) (n: number of measurements, P10: tenth percentile, Q1: first quartile, Med: median, Q3: third quartile, P9O: ninetieth percentile).

When looking at cross-sectional geometrical parameters (Figure 8), submarine sediment conduit types are significantly different (Table 1). Leveed channels appear clearly distinct from the other sediment conduits in virtue of their smaller dimensions (Figure 8). Leveed channel cross-sectional area is indeed four times lower than that of incised channels and valleys, and more than one order of magnitude lower than that of canyons (Figure 8a). Mean bankfull width and mean and maximum bankfull depths follow trends similar to that of the cross-sectional area (Figures $8 \mathrm{~b}-\mathrm{d}$ ). Canyons are the largest submarine sediment conduits, leveed channels the smallest, while incised channels and valleys show statistically similar dimensions according to every cross-sectional metrics (Figure 8 and Table 1).
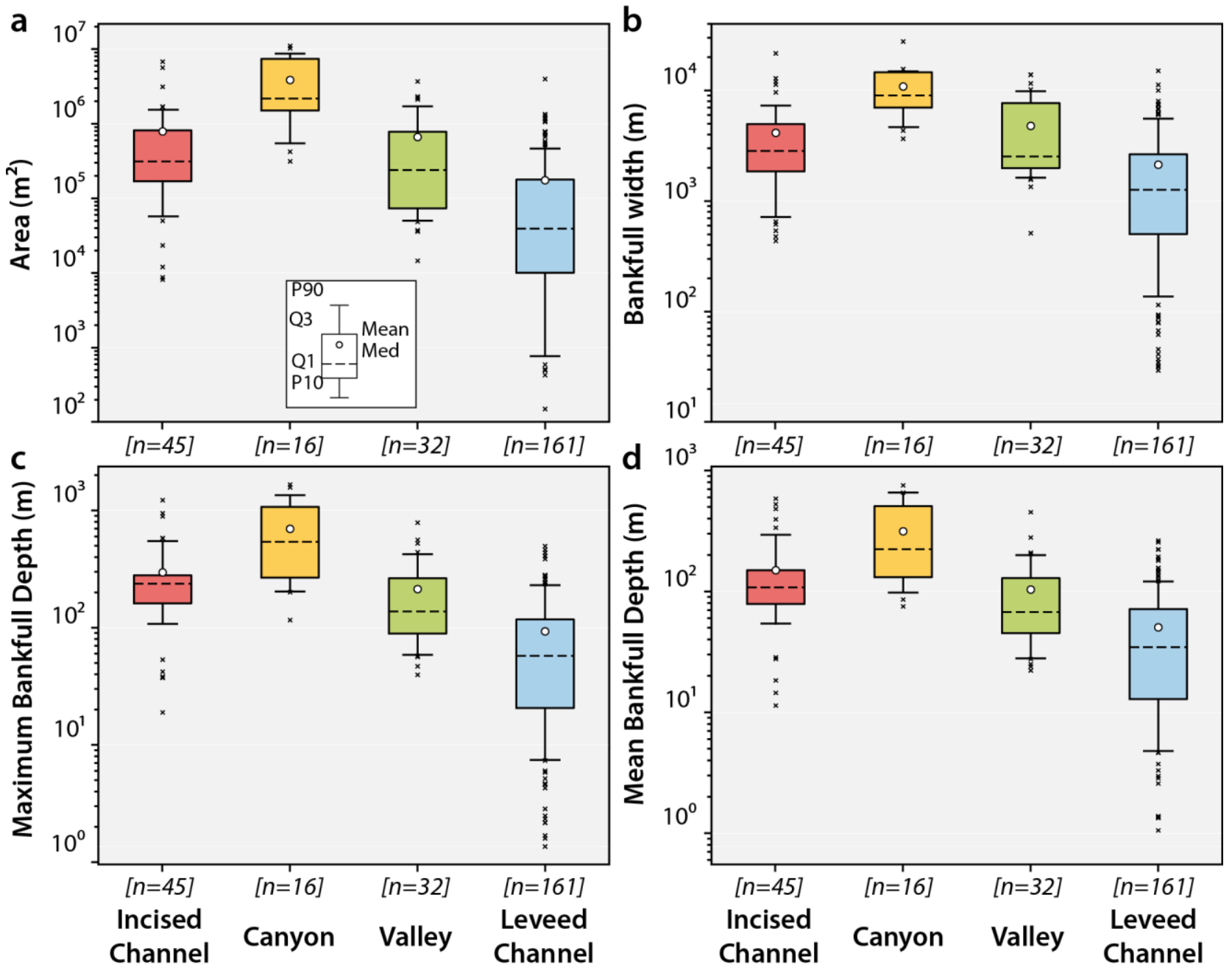
Figure 8: Cross-sectional dimensions of submarine sediment conduits: cross-sectional area (a), bankfull width (b), maximum bankfull depth (c) and mean bankfull depth (d). See Figure 7 for abbreviations.

\subsubsection{Normalized meander dimensions and cross-section ratios}

When looking at cross-sectional geometrical parameters (Figure 8), submarine sediment conduit

types are significantly different (Table 1). Leveed channels appear clearly distinct from the other sediment

conduits in virtue of their smaller dimensions despite the greatest scatter (Figure 8). Median cross-sectional area of leveed channels $\left(4.010^{4} \mathrm{~m}^{2}\right)$ is indeed 6-8 times lower than that of incised channels $\left(3210^{4} \mathrm{~m}^{2}\right)$ and valleys $\left(2410^{4} \mathrm{~m}^{2}\right)$, and nearly two orders of magnitude lower than that of canyons $\left(22210^{4} \mathrm{~m}^{2}\right.$ - Figure 8a). Bankfull width and mean and maximum bankfull depths follow trends similar to that of the crosssectional area (Figures 8b-d). Canyons (median values of $9082 \mathrm{~km}, 224 \mathrm{~m}$ and $539 \mathrm{~m}$ respectively) are the largest submarine sediment conduits, leveed channels (1267 m, $34 \mathrm{~m}$, and $57 \mathrm{~m}$ ) the smallest, while incised channels $(2866 \mathrm{~m}, 109 \mathrm{~m}$, and $237 \mathrm{~m})$ and valleys $(2556 \mathrm{~m}, 68 \mathrm{~m}$, and $137 \mathrm{~m})$ show statistically similar dimensions according to every cross-sectional metrics (Figure 8 and Table 1).
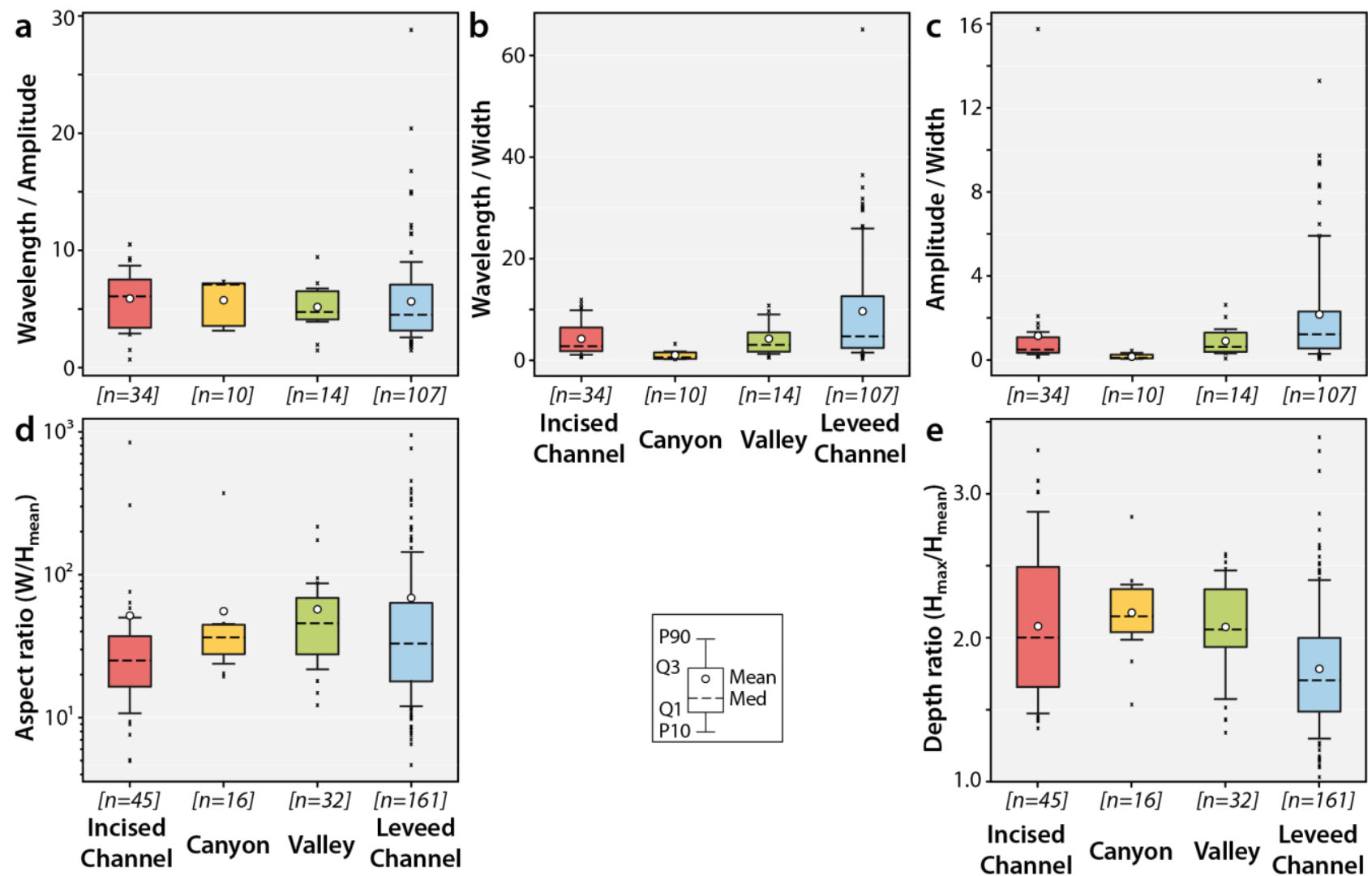
Channel Canyon Valley Channel

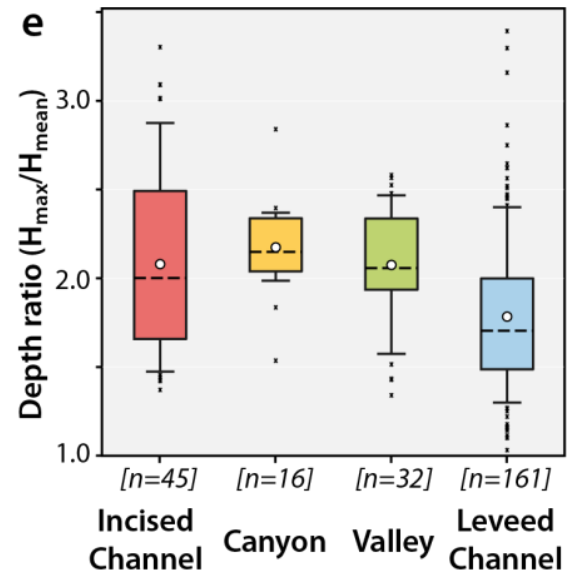


Figure 9: Normalized planform parameters: wavelength to bankfull width ratio (a), amplitude to bankfull width ratio (b), wavelength to amplitude ratio (c), and normalized cross-sectional parameters: aspect ratio (d), depth ratio (e) of submarine sediment conduits.

The aspect ratio significantly differs between valleys (median 46) and incised channels (26) whereas no statistical difference is observed between the other conduit types (median values of canyon and leveed channels of 33 and 36 respectively; table 1 and Figure 9d). Conversely, leveed channels significantly differ from canyon, valleys and incised channels in virtue of a smaller (median 1.7) depth ratio (maximum to mean bankfull depths), which tends to be higher for the latter types (> 2.0; Table 1 and Figure 9e).

\subsection{Submarine sediment conduits relationships and comparison with}

\section{alluvial sinuous rivers}

In the following, morphometric relationships are derived for all types of submarine sediment conduits and then for submarine leveed channels only (see section 2.3 for the methodology). The relationships are compared to published fluvial and submarine sediment conduits morphometric relationships established for modern systems (Table 2; Figures 10 and 11).

\subsubsection{Morphometric relationships}

Overall, results show that submarine and fluvial sediment conduits have contrasting dimensions; power law regressions differ to some degree (Figure 10). For instance, submarine sediment conduits are around four times larger than rivers for a given mean depth considering Held's data (Figure 10a). Note that width-to-depth relationships for submarine sediment conduits are very similar, considering all sediment conduits or leveed channels only (i.e., exponents of 0.81 , coefficients of 74.7 and 70.5 respectively; Figure 10a). Wavelength-to-amplitude regressions on submarine data have very similar exponents (0.93 and 0.94 ) close to that of the regression performed by Williams (1986) on river data (1.0), but with coefficients 1.83.5 times higher ( 7.89 and 7.48 for submarine data against 2.23 and 4.04 for rivers - Figure 10b). Thus, 


\begin{tabular}{|c|c|c|c|c|c|}
\hline Equation $n^{\circ}$ & System & Reference & Power law & $R^{2}$ & Sinuosity \\
\hline \multicolumn{6}{|c|}{ Meander wavelength $(\lambda)$ from meander amplitude $(A)$} \\
\hline F1 & Fluvial & Leopold and Wolman (1960) & $\lambda=4.04 A^{1.0}$ & NA & NA \\
\hline F2 & Fluvial & Williams $(1986)^{*}$ & $\lambda=2.23 A^{0.98}$ & 0.98 & $>1.3$ \\
\hline S1 & Submarine & This study (all submarine SC) & $\lambda=7.89 A^{0.93}$ & 0.88 & $>1.0$ \\
\hline S2 & Submarine & This study (leveed channel) & $\lambda=7.48 A^{0.94}$ & 0.90 & $>1.0$ \\
\hline \multicolumn{6}{|c|}{ Meander wavelength $(\lambda)$ from bankfull width $(W)$} \\
\hline F3 & Fluvial & Leopold and Wolman (1960) & $\lambda=10.9 W^{1.01}$ & NA & NA \\
\hline F4 & Fluvial & Williams (1986)* & $\lambda=7.5 W^{1.12}$ & 0.92 & $>1.3$ \\
\hline S3 & Submarine & Clark et al. (1992) & $\lambda=11.9 W^{0.75}$ & 0.68 & $>1.0$ \\
\hline S4 & Submarine & This study (all SC) & $\lambda=10.1 W^{0.88}$ & 0.47 & $>1.0$ \\
\hline S5 & Submarine & This study (leveed channel) & $\lambda=2.45 W^{1.11}$ & 0.63 & $>1.0$ \\
\hline \multicolumn{6}{|c|}{ Meander amplitude $(A)$ from bankfull width $(W)$} \\
\hline F5 & Fluvial & Leopold and Wolman (1960) & $A=2.7 W^{1.10}$ & NA & NA \\
\hline F6 & Fluvial & Williams $(1986)^{*}$ & $A=3.14 W^{1.12}$ & 0.92 & $>1.3$ \\
\hline S6 & Submarine & Clark et al. (1992) & $A=2.7 W^{1.44}$ & NA & NA \\
\hline S7 & Submarine & This study (all SC) & $A=2.75 W^{0.84}$ & 0.43 & $>1.0$ \\
\hline S8 & Submarine & This study (leveed channel) & $A=0.59 W^{1.09}$ & 0.59 & $>1.0$ \\
\hline \multicolumn{6}{|c|}{ Channel bankfull width $(W)$ from mean bankfull depth $\left(H_{\text {mean }}\right)$} \\
\hline F7 & Fluvial & Williams (1986) & $W=21.3 H_{\text {mean }}{ }^{1.45}$ & 0.66 & $>1.3$ \\
\hline F8 & Fluvial & Williams (1986) & $W=15.5 H_{\text {mean }}{ }^{1.40}$ & 0.60 & $>1.7$ \\
\hline F9 & Fluvial & Bridge and Mackey (1993) & $W=8.9 H_{\text {mean }}{ }^{1.82}$ & 0.60 & $>1.0$ \\
\hline F10 & Fluvial & Held (2011) & $W=10.9 H_{\text {mean }}{ }^{0.93}$ & 0.73 & $>1.5$ \\
\hline S9 & Submarine & Konsoer et al. (2013) & $W=47.4 H_{\text {mean }}{ }^{0.94}$ & 0.39 & $>1.0$ \\
\hline S10 & Submarine & This study (all SC) & $W=74.7 H_{\text {mean }} 0.81$ & 0.59 & $>1.0$ \\
\hline S11 & Submarine & This study (leveed channel) & $W=70.5 H_{\text {mean }} 0.81$ & 0.53 & $>1.0$ \\
\hline
\end{tabular}

submarine sediment conduits are less sinuous, as their amplitude is lower than that of sinuous rivers for a given wavelength.

In comparison with the results of Table 1, we performed a Kruskal-Wallis test and the pair-wise comparison between all submarine sediment conduits, submarine leveed channels and alluvial rivers on the aspect ratio, wavelength-to-amplitude ratio, normalized wavelength, and normalized amplitude. All of them confirmed the statistical differences between the three populations.

Table 2: Summary of modern fluvial and submarine geometric relationships. 
considering all submarine sediment conduits or submarine leveed channels only, in agreement with

normalized meander dimensions (Figures $9 \mathrm{~b}$ and 9c). In both cases, the power law exponents are lower

than 1 considering all sediment conduits ( 0.84 and 0.88 respectively; instead the exponents are greater
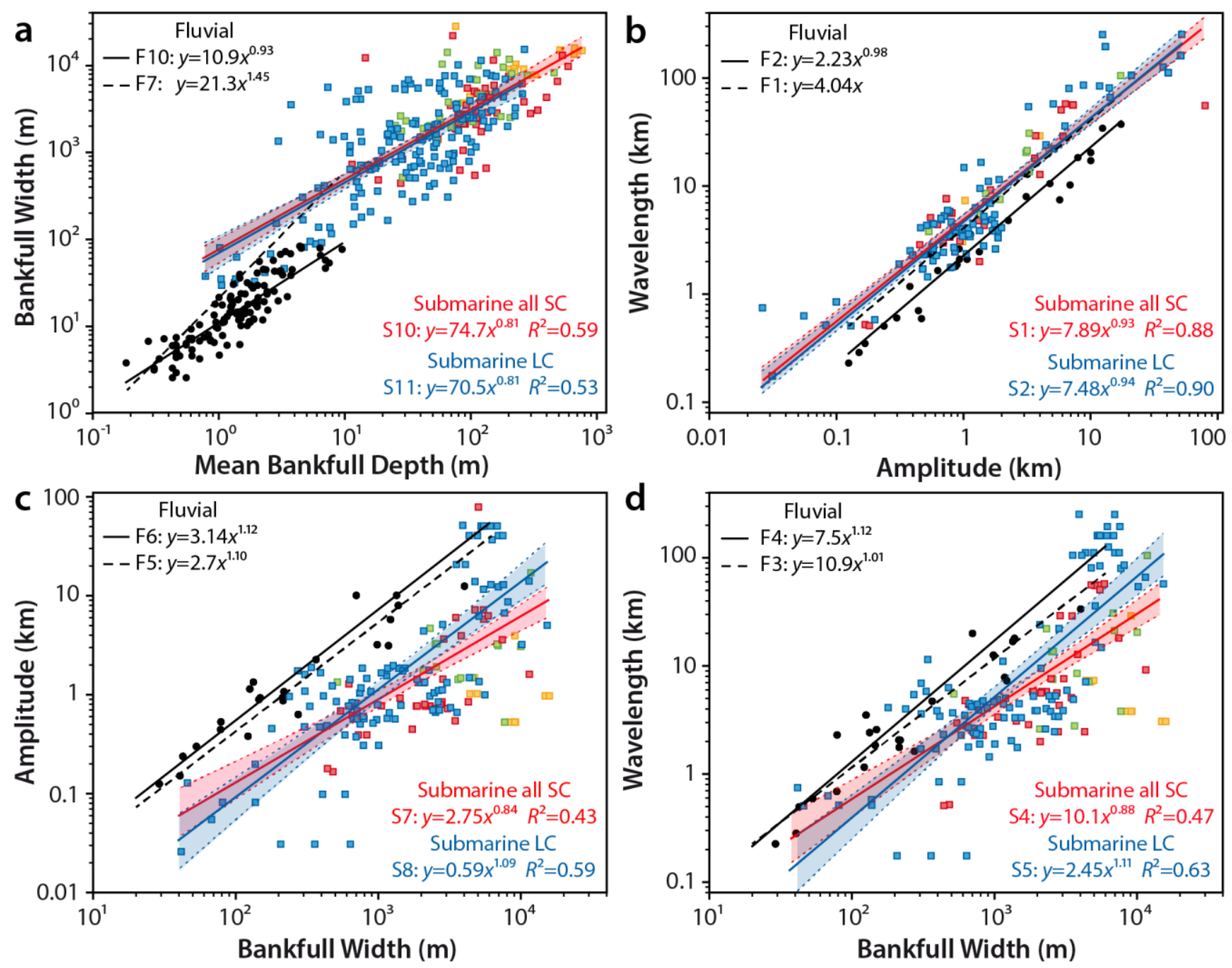

Data

- Fluvial channels (from Held, 2011)

- Incised Channel

Canyon

- Valley

Submarine Sediment Conduits (SC)

Relationships

--- Fluvial power law equations

..... Submarine LC power law regression

$\ldots . .$. and confidence interval

.... All submarine SC power law regression

$\ldots \ldots$ and confidence interval 
Figure 10: Relationships of all submarine sediment conduit and leveed channel morphometric parameters and comparison with those of sinuous rivers: bankfull width versus mean bankfull depth (a), wavelength versus amplitude (b), amplitude versus bankfull width (c), wavelength versus bankfull width (d). Fluvial data are from Held (2011) in (a) and from this study in (b) to (d). See Table 2 for the equation numbers.

\subsubsection{Cross-sectional geometry related to bed slope}

Correlations show that cross-sectional geometric parameters tend to increase with decreasing bed slope for both submarine sediment conduits and rivers (Figure 11). Bankfull width is significantly negatively correlated to slope for submarine sediment conduits, submarine leveed channels, and fluvial channels (Figure 11a), although the coefficients of determination are small (respectively $0.13,0.35$, and 0.30 ). Mean bankfull depth and slope are correlated for fluvial channels $\left(R^{2}=0.39, p\right.$-value $\left.=5.710^{-7}\right)$, but no correlation is observed for submarine sediment conduits or leveed channels alone (respectively $R^{2}=0.002$ and $0.02, p$ value $=0.46$ and 0.11 , Figure $11 \mathrm{~b}$ ). There is a very small, while significant, correlation between crosssectional area and slope for submarine sediment conduits $\left(R^{2}=0.05, p\right.$-value $\left.=0.002\right)$. A stronger correlation exists for submarine leveed channels and fluvial channels (respectively $R^{2}=0.18$ and $0.36, p$-value $=3.810^{-6}$ and $1.110^{-14}$, Figure 11c). Finally, the aspect ratio is correlated to bed slope for submarine sediment conduits $\left(R^{2}=0.19, p\right.$-value $\left.=1.4210^{-9}\right)$ and submarine leveed channels alone $\left(R^{2}=0.29, p\right.$-value $\left.=1.910^{-9}\right)$, while no correlation appears for fluvial data $\left(R^{2}=0.01, p\right.$-value $=0.18$, Figure $\left.11 \mathrm{~d}\right)$. This indicates that submarine leveed channels tend to be wider when the slope is lower (i.e., mostly going downstream). 

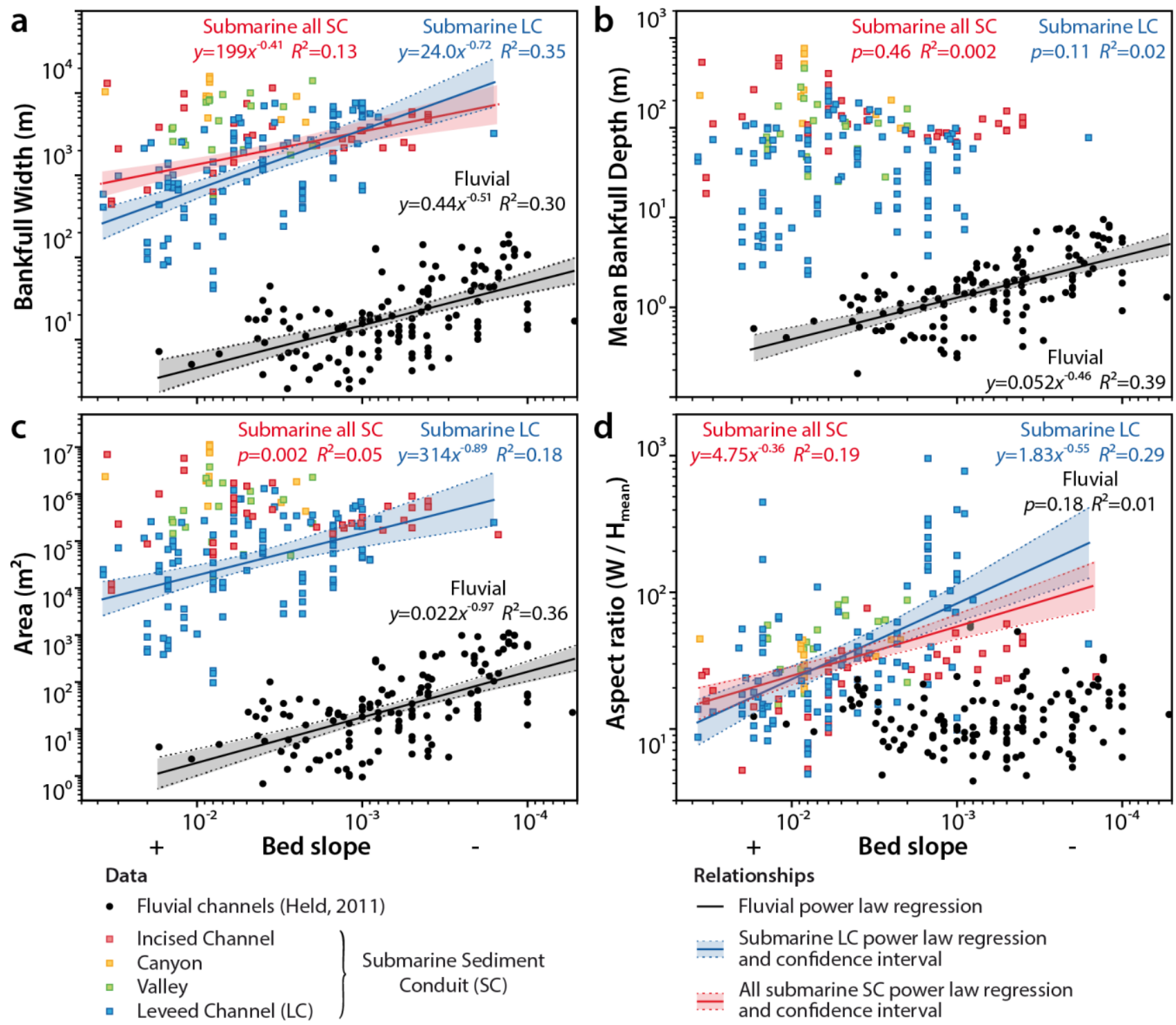

Figure 11: Cross-plots of bankfull width (a), mean bankfull depth (b), cross-sectional area (c), and aspect ratio (d) versus channel slope for all submarine sediment conduits, submarine leveed channels, and rivers. Regression curves are not represented for $p$-value $>0.05$ and/or $R^{2}<0.1$.

\section{Discussion}

To our knowledge, the present database is one of the most exhaustive compilation of modern submarine sediment conduits data from academic research publications, where sampled submarine sediment conduits extend over different geological settings, comprise varied sediment feeding systems, and include measurements in varied geomorphic locations from the edge of continental shelves to abyssal plains (Figure 5). Such compilation and the first-order trends identified between morphometric parameters 
(i.e., similarly to rivers) are of use to both field and modeling-oriented geologists for understanding submarine sediment conduit dynamics. In the following, we discuss the relevance of the new geomorphic classification and its applications, as well as the distribution of submarine sediment conduits (particularly leveed channels) and their analogy with alluvial sinuous rivers.

\subsection{First-order characteristics of submarine sediment conduits types}

\subsubsection{Relevance of the classification}

The classification of submarine sediment conduits developed in this work is based on two simple geomorphic criteria: presence/absence of levees, composite/unit nature of the studied submarine sediment conduits (Figure 2). These geomorphic criteria can be inferred from 2D cross-sections, and can be applied in absence of constraints on sediment conduit location in the submarine system (Shepard, 1965; Normark et al., 1993; Babonneau et al., 2002), or submarine sediment conduit planform morphology (e.g., braiding versus sinuous pattern, see Foreman et al., 2015 and references therein). The presence of levees indicates partly or fully constructional conduits (Normark, 1970; Wynn et al., 2007; Straub and Mohrig, 2008) while their absence indicates mosly erosional conduits (Normark, 1970; Fildani et al., 2013; Weill et al., 2014). As a result, our classification includes the two end-members "erosive" and "aggradational" submarine sediment conduits of the classification of Normark (1970) - "mixed" conduits being included into aggradational features.

The classification proposed in this study uses a unified nomenclature for modern systems, based on geomorphic features that can also be inferred in fossil systems as well as small-scale and numerical models (Lemay, 2018). The proposed hierarchical basis between unit and composite submarine sediment conduits is furthermore similar to the stratigraphic division between the smaller-scale (i.e., highest-order) channel fill deposits and the larger-scale (i.e., lower-order) stratigraphic valley fills (Mayall et al., 2006; Deptuck et al., 2007; Hodgson et al., 2011; Janocko et al., 2013b; Covault et al., 2016). Despite this hierarchical similarity, stratigraphic conduits are not directly derived from paleo-valleys since the formers are shaped 
during both incision and filling phases (Strong and Paola, 2008; Sylvester et al., 2011). This hierarchy reflects either single or multi phase submarine sediment conduit evolutions (Clark and Pickering, 1996; Deptuck et al., 2007; Babonneau et al., 2004; Bain and Hubbard, 2016). Such distinction is useful because the morphology or sedimentary architecture of composite submarine sediment conduits results from a multi-phase evolution and the interaction of different processes (Mayall et al., 2006; Strong and Paola, 2008; Deptuck et al., 2007; Sylvester et al., 2011). In this sense, our nomenclature of submarine sediment conduits is comparable to the one used for fluvial systems: modern submarine composite sediment conduits are analogous to continental canyons and valleys while modern submarine channels are analogous to rivers. In addition, sinuous streams are classically split into erosive bedrock and constructive alluvial rivers based on local sediment transport conditions (Montgomery et al., 1996 and references therein). Our classification allows to distinguish between incised and leveed channels, which may be seen as their submarine counterparts (Normark, 1970; Wynn et al., 2007; Straub and Mohrig, 2008; Fildani et al., 2013; Weill et al., 2014).

\subsubsection{Distribution of sediment conduit types along continental margins}

The distribution of submarine sediment conduit types along the continental margins shows a predominance of composite conduits on the continental slope and unit channels in the basin floor (Figure 6). This is in agreement with the existing subdivision into canyon, valley and channel used in many studies (e.g., Babonneau et al., 2002; Pirmez and Imran, 2003) but where precise and objective recognition criteria were missing (Wynn et al., 2007). Deep incised submarine sediment conduits are mostly located on the top of the continental slope while shallower leveed submarine sediment conduits are dominant in the distal part of submarine systems (Figures 6, 8 and 11). Importantly, this distribution reflects major process changes along the continental margin (Figures 1 and 5) that are likely related to geomorphic adjustment to flow conditions similarly to those taking place in rivers (Pirmez et al., 2000; Kneller, 2003; Samuel et al., 2003; Hodgson et al., 2011). The upstream part is therefore dominated by flows with high transport capacity, which can carve multiple unit erosive conduits, ultimately creating composite sediment conduits 
455 (Deptuck et al., 2007; Babonneau et al., 2004). These composite submarine sediment conduits have 456 experienced long-lived multi-phase evolution under varying discharge. In contrast, the downstream part of 457 continental margins is dominated by lower transport capacity unit submarine sediment conduits. These 458 short-lived conduits are laterally mobile, whether in the form of lateral migration or avulsion (Figure 1). 459 Hence, the classification can be used to infer paleo-environment, paleo-geographic location and 460 dimensions of the related submarine conduit from observed geomorphic features and geometry (e.g., 461 Konsoer et al., 2013; Castelino et al., 2017; Harishidayat et al., 2018).

\subsubsection{Construction of composite sediment conduits}

At first order, the different submarine sediment conduit types within the classification have contrasting dimensions, spanning several orders of magnitude (Figure 8). Canyons, valleys, and incised channels are typically five to ten times wider and deeper than leveed channels (Figure 8). The meanders of unit submarine channels are usually more developed than those of composite submarine sediment conduits which is reflected in higher wavelength-to-width and amplitude-to-width ratios (Table 1, Figures $9 \mathrm{~b}$ and $9 \mathrm{c})$, and indicates that leveed channels are more laterally mobile. Intriguingly, the wavelength-toamplitude ratio is very similar across any type of submarine conduit ( 7$)$ but differs from the typical range of 2-4 observed for fluvial meandering rivers (Tables 1 and 2, and Figure 9a). Hence, unit and composite submarine sediment conduits share common properties.

Many processes are invoked for the formation of composite submarine conduits including slumps, during lowstand of sea level (Normark et al., 1993; Antobreh and Krastel, 2006; Babonneau et al., 2004; Deptuck et al., 2007). In this study, sampled submarine canyons are the straightest conduits relatively to their width (Figures $8 \mathrm{~b}-\mathrm{c}$ ), which may support an initiation by regressive erosion, whether driven by 477 submarine retrogressive failures or subaerial carving associated with sea-level lowstand. However, the 478 similar wavelength-to-amplitude ratio between composite and unit submarine conduits (Table1, Figures 9b 479 and 9c) support the entrenchment of unit submarine channels within the composite ones (at least for most 
of the canyons present in the database), according to a mechanism similar to the formation process proposed for continental canyons -e.g., the Grand Canyon (Karlstrom et al., 2014, and references therein). Hence the sampled submarine canyons were likely carved into preexisting submarine features and have since adjusted to frequent erosive sediment-laden flows (Mulder and Alexander, 2001). Consequently, fluctuations in flow characteristics (discharge, sediment load) through time are recorded by changes in small-scale channel sedimentary body morphology and grain-size distribution, and impact the location, architecture, and petrophysical properties of hydrocarbon reservoirs within large-scale canyons or valleys (Mayall et al., 2006; Wynn et al., 2007). The smallest submarine sediment conduits are likely key elements to understand the carving and sedimentary filling of larger submarine sediment conduits. Capturing the geometry and heterogeneities of composite submarine sediment conduits therefore requires understanding the evolution of smaller confined channels. The present study provides morphometric parameters such as distributions and scaling laws for characterizing channelized sedimentary bodies relying on geometric approaches (Sylvester et al., 2011; Parquer et al., 2017; Lemay, 2018).

\subsubsection{Submarine channel dimensions}

In studies on submarine sediment conduit geometry, small submarine sediment conduits narrower than $1000 \mathrm{~m}$ and/or shallower than $10 \mathrm{~m}$ (maximum depth)- are rarely reported (e.g., Konsoer et al., 2013). In our database, $5.5 \%$ of submarine sediment conduits are less than $100 \mathrm{~m}$ wide, and $10.9 \%$ are less than $10 \mathrm{~m}$ deep (mean depth). McHargue et al. (2011) developed from outcrops the concept of "channel elements" up to four times narrower and shallower than the unit channels identified in this study. One may thus question to what extent our database is representative of submarine channel dimensions. Although very large channels $(>5000 \mathrm{~m}$ ) are observed on modern ocean floors (e.g., Zambezi channel Wiles et al., 2017), some of the largest channels we identified (particularly from old data) may in fact correspond to composite submarine sediment conduits (see Supplementary Material). For example, many incised sediment conduits on the top of the continental slope, for instance the Amazon, Bengal or Indus systems, do not display any entrenched smaller conduit, while a multi-phase evolution of such systems is 
undeniable. Consequently, some of the incised channels in our database, particularly those on the shelf break, could be reclassified as canyons. This may partly explain the great scatter of unit channel data particularly the very large channels observed in our database- but also the low number of canyons identified from our classification. Conversely, small submarine sediment conduits are locally reported in 3D seismic surveys, for instance in frontal lobes (Doughty-Jones et al., 2017) or carbonate systems (Mulder et al., 2014). However, low data resolution prevents from precisely measuring them. We therefore acknowledge that the present dataset may consider composite sediment conduits as unit ones, and that, without access to higher-resolution recent data (e.g., from the industry), very small submarine sediment conduits ( $<100 \mathrm{~m}$ wide or $10 \mathrm{~m}$ deep) may not be sampled. However, we emphasize that this limitation should not affect the major trends observed in this study since it concerns a minority of our data, and considering that the dataset covers three orders of magnitude, which highlights the larger size of composite submarine sediment conduits compared to unit channels (Table 1), and unit channels compared to rivers.

\subsection{Submarine leveed channel flow processes}

\subsubsection{Comparison with fluvial meandering channels dynamics}

As observed in other studies (Clark and Pickering, 1996; Pirmez and Imran, 2003; Konsoer et al., 2013), surveyed submarine sediment conduits are one to two orders of magnitude wider and deeper than alluvial sinuous channels (Figures 11 and 12a). Among them, submarine leveed channels are the most analogous to alluvial rivers: (i) they have an aggradational behavior; (ii) they form a consistent group that significantly differ from the other submarine sediment conduit types (Table 1) in virtue of (iii) a smaller size

(Figure 7b), (iv) larger meanders relatively to their size (Figures 9a-9c); (v) they display wavelength-to-width and amplitude-to-width relationships more similar to those of sinuous alluvial rivers than those of all submarine sediment conduits (Figures $9 \mathrm{~b}$ and 9c); and finally (vi) they typically show downstream increases of both channel width and cross-sectional area similarly to most of rivers (Figures 11a, 11c and 12a), although unlike rivers they do not present an increase in depth (Figure 11b). 
Although they are the overall smallest submarine sediment conduit type, submarine leveed 530 channels remain one order of magnitude wider and deeper than fluvial sinuous channels (i.e., Figures 11 , 531 12a). $90 \%$ of the sampled submarine leveed channels are between 100 and $2000 \mathrm{~m}$ wide and between 10 and $100 \mathrm{~m}$ deep (maximum bankfull depth). Submarine leveed channels are also four times wider than rivers for a given mean depth, since their bankfull width is around 37 times the mean depth (Figures 10a and 12a). This ratio is 1.5 times lower than proposed by Konsoer et al. (2013). This result likely reflects the influence of the large proportion of submarine sediment conduits narrower than $1000 \mathrm{~m}$ in our study (40\%) compared to Konsoer et al. (2013) (5\%) since small-size submarine sediment conduits (i.e., leveed channels) have on average the highest aspect ratios (Figures $9 \mathrm{~d}$ and 10a). Leveed channels presented in this study are therefore relatively small elements in the hierarchy of the submarine realm. They are close to the unit submarine sediment conduits building larger sedimentary bodies, similarly to individual sinuous streams in alluvial plains. The relationships derived from leveed channels (Table 2 and Figure 12) thus provide the first order trends in terms of morphometric parameter scaling, which may be used to calibrate submarine leveed channel models, and to highlight (dis-)similarities of channel morphology depending on geological settings (latitude, margin type, feeder system, sediment load) in natural systems.

Amplitude and wavelength of submarine leveed channel meanders are three times smaller than those of fluvial meanders with respect to channel width (Figures 10b-10d and 12a) in agreement with data from the Amazon fan (Pirmez and Imran, 2003). This reflects a reduced growth of meander interpreted as a stabilization of the flow path, which is much less pronounced in fluvial channels (Peakall et al., 2000; Jobe et al., 2016). Hence, similarly to alluvial sinuous rivers, this supports that curvature drives flow asymmetry and migration of submarine leveed channels (Imran et al., 1999; Sylvester et al., 2011). The reduced growth of submarine meander would then more likely be the result of either clay hysteresis in the upper flow layers (Peakall et al., 2000), high vertical accretion rates (Jobe et al., 2016), or change of secondary circulation patterns (Azpiroz-Zabala et al., 2017). 


\section{Submarine Leveed Channels}

\begin{tabular}{|lcl|}
\hline & Median (m) & Relationship \\
$H_{\text {mean }}$ & 34 & - \\
$W$ & 1270 & $70.5 \mathrm{H}_{\text {mean }} .81$ \\
$A$ & 1090 & $0.59 \mathrm{~W}^{1.09}$ \\
$\lambda$ & 4200 & $2.45 \mathrm{~W}^{\text {W.11 }}$ \\
$\lambda$ & - & $7.48 \mathrm{~A}^{0.94}$ \\
\hline
\end{tabular}

Morphometric scaling also reflects channel and flow dynamics as shown for fluvial systems. Two main complementary theories explain the relationships between alluvial river planform morphology, crosssectional geometry, and bankfull discharge. On the one hand, the stability analysis of Parker (1976) defines a single-thread to braided channel transition criterion, which may be observed experimentally (Foreman et al., 2015). On the other hand Lacey's law considers that channel dimensions adapt to flow and sediment discharges as long as the banks are maintained at their threshold of sediment motion (Lacey, 1930; Métivier et al., 2017 and references therein). As such, channel width, mean depth, and the inverse of bed slope are linked together and proportional to the square root of flow discharge. The relationships between submarine leveed-channel cross-sectional parameters and slope indicate that these parameters are correlated in a manner similar to fluvial systems, although with the noticeable exception of channel depth (Figure 11). The latter may evolve non-monotonically with bed slope, which could tentatively be related to a loss of confinement for distal turbidite flow (see next section). Equilibrium between submarine channel geometry and flow discharge was hypothesized by several studies (Janocko et al., 2013a; Konsoer et al., 
572 fluvial and submarine datasets is explained by the differences in terms of driving force and used this shift to 573 estimate submarine flow concentration and velocity. This study thus supports their initial assumption for channel area and width, but not for depth (Figure 11). Consequently, concentration, velocity and then flow discharge can be better estimated using the driving force from channel width or area. In addition, submarine leveed channels significantly differ from the other submarine conduits according to the depth ratio equal to 1.7 (Table1, Figure 9e), which is roughly equivalent to the depth ratio according to the Lacey's law $(\pi / 2)$. The fact that such scaling applies in the submarine realm as well further supports similar channelformative processes.

This result suggests that the fluvial concept of channel-forming discharge (Wolman and Miller 1960; Blom et al., 2017 and references therein) may be transposed to submarine systems. Following the fluvial definition, the submarine channel-forming discharge corresponds to the steady discharge that provides the same channel geometry as the succession of intermittent and varied submarine flows. This concept can be used for instance to simulate the long-term evolution of submarine channels by inferring their channelforming discharge from their geometry (Lemay, 2018). downstream as shown by the small negative correlation of width and cross-sectional area with channel slope (Figures 11a and 11c). There is however no correlation between channel depth and slope, which could be due to a non-monotonous relationship (Figure 11b). This contrasts with observations from studies dealing with individual systems, which most often show constant or decreasing cross-sectional dimensions downstream (Shumaker et al., 2018). Although these studies include the width of composite conduits and not only that of unit channels in the upstream part of submarine systems, they reflect the complexity of the 594 submarine leveed channel geometry evolution. The present compilation may miss this complexity because 595 it is a worldwide set, which does not capture slope variations along a given system. Other phenomena may 
be also at play such as the downstream decrease of levee thickness as pointed by Skene et al. (2002) on six submarine systems and by Shumaker et al. (2018) on the Bengal system.

Perennial alluvial rivers used in the fluvial database are tributary systems, in which discharge increases downstream while slope decreases (Held, 2011 and references therein) and channel dimensions proportionally increase (Leopold and Maddock, 1953; Williams, 1978). In contrast, most submarine leveed channels in our database belong to distributary systems. Similarly to the fluvial systems, submarine channel slope decreases downstream, but conversely submarine flow discharge is most likely to decrease due to flow overspill and sediment deposition (Hiscott et al., 1997; Konsoer et al., 2013; Traer et al., 2018). Hence, without discharge contribution from tributaries, long-running submarine flows increase their width and area as they migrate towards the abyssal plains (Figures 11a, 11c), a behavior that does not follow that of fluvial systems.

This apparent contradiction with the Lacey's law can be explained as follow. Contrarily to fluvial systems where the flow discharge is not affected by the sediment load (Konsoer et al., 2013), submarine flows grow because of sediment entrainment from the bed (Parker et al., 1986; Garcia and Parker, 1993). This phenomenon is observed particularly for supercritical currents initiated on steep slopes such as the continental slope, but becomes less significant for subcritical currents flowing on gentle slopes in the distal part of submarine systems (Pirmez and Imran, 2003). In this case, numerical simulations (Dorrell et al., 2014; Luchi et al., 2018) -confirmed by natural observations (Paull et al., 2018)- invoked the role of flow stratification to create a steady coarse-grained basal driving layer overlaid by a dilute fine-grained driven layer. This steady coarse-grained basal driving layer defines the submarine flow forming discharge in the sense of Wolman and Miller (1960), which controls submarine leveed channel dimensions according to the threshold theory (Métivier et al., 2017). Consequently, a roughly constant or slowly decreasing discharge corresponding to the basal layer- may be maintained for long distances inside the channel, while the upper layer progressively vanishes due to flow overspill (Hiscott et al., 1997; Konsoer et al., 2013; Traer et al., 2018). This results in downstream decrease of levee height (Skene et al., 2002) and then loss of confinement (Shumaker et al., 2018). Flow overspill is also responsible for the loss of the finest sediments 
leading to coarsen the sediment load and levee deposits (Dorrell et al., 2014; Dennielou et al., 2017); this contributes to reduce flow and bank cohesion, as well as sediment friction angle. Both effects result in down-slope channel aspect ratio increase and potentially channel widening (Figures 11a and 11d) favoring the development of a braiding pattern (e.g., Foreman et al., 2015) and/or ultimately to the building of terminal lobes in the lower fan.

\section{Conclusions}

This study used an extensive dataset based on available publications to analyze the geometry and dynamics of modern submarine sediment conduits. We defined a new classification of submarine sediment conduits into four types based on two geomorphic criteria: presence/absence of flanking levees, composite/unit nature of the submarine sediment conduits. This scheme allows for a precise definition of submarine canyons, valleys and channels either erosive or leveed. Morphometric parameters of these submarine sediment conduits were measured according to a survey methodology adapted from the fluvial one.

We found that:

- (1) the continental margin strongly controls submarine sediment conduit geomorphology, longlived, mostly erosive, composite submarine sediment conduits being located on the continental slope, and short-lived, mostly constructive, unit channels in the basin floor;

- (2) submarine unit leveed channels form a statistically significant and consistent group of constructive, smaller and lateral mobile sediment conduits;

- (3) submarine unit leveed channels display planform and cross-sectional morphometric relationships the most similar to alluvial sinuous rivers. Consequently, submarine unit leveed channels are the most analogous to alluvial sinuous rivers;

(4) without discharge contribution from tributaries, long-running submarine flows can increase their width and area as they migrate towards the abyssal plains similarly to rivers. The latter 

cohesion, and associated decreasing friction angle.

Finally, the classification associated with the distributions of submarine sediment conduits can be 649 used to infer paleo-environments. These laws and the morphometric relationships provide the first order 650 trends in terms of parameter scaling, which may be used to calibrate submarine channelized system 651 models.

\section{Acknowledgement}

654 supported by the Flumy research program Armines / MINES ParisTech. The Flumy research program 655 sponsors, ENGIE (now Neptune Energy) and ENI, are acknowledged for financial support and fruitful 656 discussions. The authors thank D. Turmel for sharing the data on the Wabush lake system, F. Palm and two 657 anonymous reviewers whose comments greatly improved the paper. 


\section{References}

660

Abreu, V., Sullivan, M., Pirmez, C., \& Mohrig, D. (2003). Lateral accretion packages (LAPs): an important reservoir element in deep water sinuous channels. Marine and Petroleum Geology, 20(6-8), 631-648. https://doi.org/10.1016/j.marpetgeo.2003.08.003.

Allen, J.R.L., (1984), Developments in Sedimentology, 663 pp., Elsevier Sci., New York.

Allen, P. A. (2017). Sediment routing systems: The fate of sediment from source to sink. Cambridge University Press.

Antobreh, A. A., \& Krastel, S. (2006). Morphology, seismic characteristics and development of Cap Timiris Canyon, offshore Mauritania: a newly discovered canyon preserved-off a major arid climatic region. Marine and Petroleum Geology, 23(1), 37-59. https://doi.org/10.1016/j.marpetgeo.2005.06.003.

Azpiroz-Zabala, M., Cartigny, M. J., Sumner, E. J., Clare, M. A., Talling, P. J., Parsons, D. R., \& Cooper, C. (2017). A general model for the helical structure of geophysical flows in channel bends. Geophysical research letters, 44(23). https://doi.org/10.1002/2017GL075721.

Babonneau, N., Savoye, B., Cremer, M., Bez, M., (2004). Mutliple terraces within the deep incised Zaire Valley (ZaiAngo Project): are they confined levees? In: Lomas, S.A., Joseph, P. (Eds.), Geological Society Special Publications, vol. 222, pp. 91-114 https://doi.org/10.1144/GSL.SP.2004.222.01.06.

Babonneau, N., Savoye, B., Cremer, M., \& Klein, B. (2002). Morphology and architecture of the present canyon and channel system of the Zaire deep-sea fan. Marine and Petroleum Geology, 19(4), 445-467. https://doi.org/10.1016/S0264-8172(02)00009-0.

Bain, H. A., \& Hubbard, S. M. (2016). Stratigraphic evolution of a long-lived submarine channel system in the Late Cretaceous Nanaimo Group, British Columbia, Canada. Sedimentary Geology, 337, 113-132. https://doi.org/10.1016/j.sedgeo.2016.03.010.

Baker, E.; Gaill, F., Karageorgis, A., Lamarche, G., Narayanaswamy, B., Parr, J., et al. (2016). Offshore Mining Industries. In The First Global Integrated Marine Assessment; World Ocean Assessment I; United Nations (UN): New York, NY, USA.

Blom, A., Arkesteijn, L., Chavarrías, V., \& Viparelli, E. (2017). The equilibrium alluvial river under variable flow and its channel-forming discharge. Journal of Geophysical Research: Earth Surface, 122(10), 1924 1948. https://doi.org/10.1002/2017JF004213.

Bridge, J. S. (2003). Rivers and Floodplains, 491 pp. Blackwell, Oxford, UK.

Bridge, J. S., \& Mackey, S. D. (1993). A theoretical study of fluvial sandstone body dimensions, in Flint, S.S., and Bryant, I.D., eds., The Geological Modelling of Hydrocarbon Reservoirs and Outcrop Analogues: International Association of Sedimentologists, Special Publication 15, p. 213-236.

Carter, R. M., \& Carter, L. (1987). The Bounty Channel system: A 55-million-year-old sediment conduit to the deep sea, southwest Pacific Ocean. Geo-marine letters, 7(4), 183-190. https://doi.org/10.1007/BF02242770.

Castelino, J. A., Reichert, C., \& Jokat, W. (2017). Response of Cenozoic turbidite system to tectonic activity and sea-level change off the Zambezi Delta. Marine Geophysical Research, 38(3), 209-226. https://doi.org/10.1007/s11001-017-9305-8.

Clark, J. D., Kenyon, N. H., \& Pickering, K. T. (1992). Quantitative analysis of the geometry of submarine channels: implications for the classification of submarine fans. Geology, 20(7), 633-636. https://doi.org/10.1130/0091-7613(1992)020\%3C0633:QAOTGO\%3E2.3.CO;2.

Clark, J.D., \& Pickering, K.T., (1996). Submarine Channels: Processes and Architecture. Vallis Press, London, $232 \mathrm{p}$.

Covault, J. A., Sylvester, Z., Hubbard, S. M., Jobe, Z. R., \& Sech, R. P. (2016). The stratigraphic record of submarine-channel evolution. The Sedimentary Record, 14(3), 4-11. https://doi.org/10.2110/sedred.2016.3.

Curray, J. R., Emmel, F. J., \& Moore, D. G. (2003). The Bengal Fan: morphology, geometry, stratigraphy, history and processes. Marine and Petroleum Geology, 19(10), 1191-1223. https://doi.org/10.1016/S0264-8172(03)00035-7. 
De Leeuw, J., Eggenhuisen, J. T., \& Cartigny, M. J. (2018). Linking submarine channel-levee facies and architecture to flow structure of turbidity currents: insights from flume tank experiments. Sedimentology, 65(3), 931-951. https://doi.org/10.1111/sed.12411.

Dennielou, B., Droz, L., Babonneau, N., Jacq, C., Bonnel, C., Picot, M., ... \& Olu, K. (2017). Morphology, structure, composition and build-up processes of the active channel-mouth lobe complex of the Congo deep-sea fan with inputs from remotely operated underwater vehicle (ROV) multibeam and video surveys. Deep Sea Research Part II: Topical Studies in Oceanography, 142, 25-49. https://doi.org/10.1016/j.dsr2.2017.03.010.

Deptuck, M. E., Sylvester, Z., Pirmez, C., \& O'Byrne, C. (2007). Migration-aggradation history and 3-D seismic geomorphology of submarine channels in the Pleistocene Benin-major Canyon, western Niger Delta slope. Marine and Petroleum Geology, 24(6-9), 406-433. https://doi.org/10.1016/j.marpetgeo.2007.01.005.

Dorrell, R. M., Darby, S. E., Peakall, J., Sumner, E. J., Parsons, D. R., \& Wynn, R. B. (2014). The critical role of stratification in submarine channels: Implications for channelization and long runout of flows. Journal of Geophysical Research: Oceans, 119(4), 2620-2641. https://doi.org/10.1002/2014JC009807.

Dorrell, R. M., Peakall, J., Burns, C., \& Keevil, G. M. (2018). A novel mixing mechanism in sinuous seafloor channels: Implications for submarine channel evolution. Geomorphology, 303, 1-12. https://doi.org/10.1016/j.geomorph.2017.11.008.

Doughty-Jones, G., Mayall, M., \& Lonergan, L. (2017). Stratigraphy, facies, and evolution of deep-water lobe complexes within a salt-controlled intraslope minibasin. AAPG Bulletin, 101(11), 1879-1904. https://doi.org/10.1306/01111716046.

Dunn, O. J. (1964). Multiple comparisons using rank sums. Technometrics, 6(3), 241-252. http://doi.org/10.2307/1266041.

Ellison, T. H., \& Turner, J. S. (1959). Turbulent entrainment in stratified flows. Journal of Fluid Mechanics, 6(3), 423-448. https://doi.org/10.1017/S0022112059000738.

Fildani, A., Hubbard, S. M., Covault, J. A., Maier, K. L., Romans, B. W., Traer, M., \& Rowland, J. C. (2013). Erosion at inception of deep-sea channels. Marine and Petroleum Geology, 41, 48-61. https://doi.org/10.1016/j.marpetgeo.2012.03.006.

Foreman, B. Z., Lai, S. Y., Komatsu, Y., \& Paola, C. (2015). Braiding of submarine channels controlled by aspect ratio similar to rivers. Nature Geoscience, 8(9), 700. https://doi.org/10.1038/ngeo2505.

Friedkin, J.F., (1945). A Laboratory Study of the Meandering of Alluvial Rivers. U.S. Army Corps Eng., Waterways Exp. Stn., Vicksburg, 40 pp.

Galy, V., France-Lanord, C., Beyssac, O., Faure, P., Kudrass, H., Palhol, F. (2007). Efficient organic carbon burial in the Bengal fan sustained by the Himalayan erosional system. Nature 450 (7168), 407. https://doi.org/10.1038/nature06273.

Garcia, M., \& Parker, G. (1993). Experiments on the entrainment of sediment into suspension by a dense bottom current. Journal of Geophysical Research: Oceans, 98(C3), 4793-4807. https://doi.org/10.1029/92JC02404.

Graham, S. A., \& Bachman, S. B. (1983). Structural controls on submarine-fan geometry and internal architecture: upper La Jolla fan system, offshore southern California. AAPG Bulletin, 67(1), 83-96.

Hansen, L. A., Callow, R. H., Kane, I. A., Gamberi, F., Rovere, M., Cronin, B. T., \& Kneller, B. C. (2015). Genesis and character of thin-bedded turbidites associated with submarine channels. Marine and Petroleum Geology, 67, 852-879. https://doi.org/10.1016/j.marpetgeo.2015.06.007.

Hansen, L., Janocko, M., Kane, I., \& Kneller, B. (2017). Submarine channel evolution, terrace development, and preservation of intra-channel thin-bedded turbidites: Mahin and Avon channels, offshore Nigeria. Marine Geology, 383, 146-167. https://doi.org/10.1016/j.margeo.2016.11.011.

Harishidayat, D., Omosanya, K. O., Johansen, S. E., Eruteya, O. E., \& Niyazi, Y. (2018) Morphometric analysis of sediment conduits on a bathymetric high: Implications for palaeoenvironment and hydrocarbon prospectivity. Basin Res. 30:1015-1041. https://doi.org/10.1111/bre.12291.

Heezen, B. C., Tharp, M., \& Ewing, M. (1959). The floors of the oceans: I. The North Atlantic (Vol. 65). Geological Society of America. 
Held, A.-E. (2011). Apport de la paléohydrologie dans la quantification des rôles respectifs du climat et de la tectonique des systèmes fluviatiles méandriformes fossiles. Application à des systèmes oligomiocènes d'Europe occidentale. (Doctoral dissertation, Ecole nationale supérieure des mines de Paris). Retrieved from theses.fr (https://www.theses.fr/2011ENMP0008).

Heller, P. L., \& Paola, C. (1996). Downstream changes in alluvial architecture; an exploration of controls on channel-stacking patterns. Journal of Sedimentary Research, 66(2), 297-306. https://doi.org/10.1306/D4268333-2B26-11D7-8648000102C1865D.

Hesse, R., Klaucke, I., Khodabakhsh, S., Piper, D. J., Ryan, W. B., \& NAMOC Study Group. (2001). Sandy submarine braid plains: potential deep-water reservoirs. AAPG bulletin, 85(8), 1499-1521.

Hiscott, R. N., Hall, R. R., \& Pirmez, C. (1997). Turbidity-current overspill from the Amazon Channel: texture of the silt/sand load, paleoflow from anisotropy of magnetic susceptibility, and implications for flow processes. In R. D. Flood, D. J. W. Piper, A. Klaus, \& L. C. Peterson (Eds.), (Vol. 155) (pp. 53-78). 1997 Proceedings of the Ocean Drilling Program, Scientific Results.

Hodgson, D. M., Di Celma, C. N., Brunt, R. L., \& Flint, S. S. (2011). Submarine slope degradation and aggradation and the stratigraphic evolution of channel-levee systems. Journal of the Geological Society, 168(3), 625-628. https://doi.org/10.1144/0016-76492010-177.

Hollander, M., Wolfe, D. A., \& Chicken, E. (2013). Nonparametric statistical methods (Vol. 751). John Wiley \& Sons.

Huvenne, V. A., \& Davies, J. S. (2014). Towards a new and integrated approach to submarine canyon research. Introduction. Deep Sea Research Part II: Topical Studies in Oceanography, 104, 1-5.

Imran, J., Parker, G., \& Pirmez, C. (1999). A nonlinear model of flow in meandering submarine and subaerial channels. Journal of Fluid Mechanics, 400, 295-331. https://doi.org/10.1017/\$0022112099006515.

Janocko, M., Cartigny, M. B. J., Nemec, W., \& Hansen, E. W. M. (2013a). Turbidity current hydraulics and sediment deposition in erodible sinuous channels: laboratory experiments and numerical simulations. Marine and Petroleum Geology, 41, 222-249. https://doi.org/10.1016/j.marpetgeo.2012.08.012.

Janocko, M., Nemec, W., Henriksen, S., \& Warchoł, M. (2013b). The diversity of deep-water sinuous channel belts and slope valley-fill complexes. Marine and Petroleum Geology, 41, 7-34. https://doi.org/10.1016/j.marpetgeo.2012.06.012.

Jefferson, M. (1902). Limiting width of meander belts. National Geographic Society.

Jobe, Z. R., Howes, N. C., \& Auchter, N. C. (2016). Comparing submarine and fluvial channel kinematics: Implications for stratigraphic architecture. Geology, 44(11), 931-934. https://doi.org/10.1130/G38158.1.

Kane, I. A., \& Clare, M. (2019). Dispersion, accumulation and the ultimate fate of microplastics in deepmarine environments: A review and future directions. https://doi.org/10.31223/osf.io/ahjes.

Kane, I. A., \& Hodgson, D. M. (2011). Sedimentological criteria to differentiate submarine channel levee subenvironments: exhumed examples from the Rosario Fm.(Upper Cretaceous) of Baja California, Mexico, and the Fort Brown Fm.(Permian), Karoo basin, S. Africa. Marine and Petroleum Geology, 28(3), 807-823. https://doi.org/10.1016/j.marpetgeo.2010.05.009.

Karlstrom, K. E., Lee, J. P., Kelley, S. A., Crow, R. S., Crossey, L. J., Young, R. A., ... \& Shuster, D. L. (2014). Formation of the Grand Canyon 5 to 6 million years ago through integration of older palaeocanyons. Nature Geoscience, 7(3), 239. http://doi.org/10.1038/ngeo2065.

Kneller, B. (2003). The influence of flow parameters on turbidite slope channel architecture. Marine and Petroleum Geology, 20(6-8), 901-910. https://doi.org/10.1016/j.marpetgeo.2003.03.001

Kondolf, G. M. (2016). Tools in fluvial geomorphology. John Wiley \& Sons.

Konsoer, K., Zinger, J., \& Parker, G. (2013). Bankfull hydraulic geometry of submarine channels created by turbidity currents: relations between bankfull channel characteristics and formative flow discharge. Journal of Geophysical Research: Earth Surface, 118(1), 216-228. https://doi.org/10.1029/2012JF002422.

Kruskal, W. H., \& Wallis, W. A. (1952). Use of ranks in one-criterion variance analysis. Journal of the American statistical Association, 47(260), 583-621. https://doi.org/10.1080/01621459.1952.10483441.

Lacey, G. (1930). Stable channels in alluvium, in: Minutes of the Proceedings of the Institution of Civil Engineers, Thomas Telford-ICE Virtual Library, 229, 259-292. 
Lemay, M. (2018) Transposition to the channelized submarine environment of a model of meandering fluvial systems in the view of reservoir modeling. (Doctoral dissertation, MINES ParisTech - PSL University). Retrieved from these.fr (https://www.theses.fr/en/s157332).

Leopold, L. B., \& Maddock, T. (1953). The hydraulic geometry of stream channels and some physiographic implications (Vol. 252). US Government Printing Office.

Leopold, L. B., \& Wolman, M. G. (1957). River channel patterns: braided, meandering, and straight. US Government Printing Office.

Leopold, L. B., \& Wolman, M. G. (1960). River meanders. Geological Society of America Bulletin, 71(6), 769793. https://doi.org/10.1130/0016-7606(1960)71[769:RM]2.0.CO;2.

Limaye, A. B., Grimaud, J. L., Lai, S. Y., Foreman, B. Z., Komatsu, Y., \& Paola, C. (2018). Geometry and dynamics of braided channels and bars under experimental density currents. Sedimentology, 65: 19471972. https://doi.org/10.1111/sed.12453

Lopez, S., Cojan, I., Rivoirard, J., \& Galli, A. (2008). Process-based stochastic modelling: meandering channelized reservoirs. Analogue and Numerical Modelling of Sedimentary Systems: From Understanding to Prediction, Wiley, Oxford, UK, 139-144.

Luchi, R., Balachandar, S., Seminara, G., \& Parker, G. (2018). Turbidity currents with equilibrium basal driving layers: A mechanism for long runout. Geophysical Research Letters, 45, 1518-1526. https://doi.org/10.1002/2017GL075608.

Mayall, M., Jones, E., \& Casey, M. (2006). Turbidite channel reservoirs-Key elements in facies prediction and effective development. Marine and Petroleum Geology, 23(8), 821-841. https://doi.org/10.1016/j.marpetgeo.2006.08.001.

McHargue, T., Pyrcz, M. J., Sullivan, M. D., Clark, J. D., Fildani, A., Romans, B., W., et al. (2011). Architecture of turbidite channel systems on the continental slope: patterns and predictions. Marine and Petroleum Geology, 28(3), 728-743. https://doi.org/10.1016/j.marpetgeo.2010.07.008.

Métivier, F., Lajeunesse, E., \& Devauchelle, O. (2017). Laboratory rivers: Lacey's law, threshold theory, and channel stability. Earth Surface Dynamics, 5(1), 187-198. https://doi.org/10.5194/esurf-5-187-2017.

Montgomery, D. R., Abbe, T. B., Buffington, J. M., Peterson, N. P., Schmidt, K. M., \& Stock, J. D. (1996). Distribution of bedrock and alluvial channels in forested mountain drainage basins. Nature, 381(6583), 587. https://doi.org/10.1038/381587a0.

Mulder, T., \& Alexander, J. (2001). The physical character of subaqueous sedimentary density flows and their deposits. Sedimentology, 48(2), 269-299. https://doi.org/10.1046/j.1365-3091.2001.00360.x.

Mulder, T., Ducassou, E., Gillet, H., Hanquiez, V., Principaud, M., Chabaud, L., ... \& Fournier, F. (2014). First discovery of channel-levee complexes in a modern deep-water carbonate slope environment. Journal of Sedimentary Research, 84(11), 1139-1146. https://doi.org/10.2110/jsr.2014.90.

Normark, W. R. (1970). Growth patterns of deep-sea fans. AAPG bulletin, 54(11), 2170-2195.

Normark, W. R., Posamentier, H., \& Mutti, E. (1993). Turbidite systems: state of the art and future directions. Reviews of Geophysics, 31(2), 91-116. https://doi.org/10.1029/93RG02832.

O'Cofaigh, C., Dowdeswell, J. A., \& Kenyon, N. H. (2006). Geophysical investigations of a high-latitude submarine channel system and associated channel-mouth lobe in the Lofoten Basin, Polar North Atlantic. Marine Geology, 226(1-2), 41-50. https://doi.org/10.1016/j.margeo.2005.09.014.

Ono, K., \& Plink-Björklund, P. (2018). Froude supercritical flow bedforms in deepwater slope channels? Field examples in conglomerates, sandstones and fine-grained deposits. Sedimentology, 65(3), 639-669. https://doi.org/10.1111/sed.12396.

Parker, G. (1976). On the cause and characteristic scales of meandering and braiding in rivers. Journal of fluid mechanics, 76(3), 457-480. https://doi.org/10.1017/S0022112076000748.

Parker, G., Fukushima, Y., \& Pantin, H. M. (1986). Self-accelerating turbidity currents. Journal of Fluid Mechanics, 171, 145-181. https://doi.org/10.1017/S0022112086001404.

Parquer, M. N., Collon, P., \& Caumon, G. (2017). Reconstruction of channelized systems through a conditioned reverse migration method. Mathematical Geosciences, 49(8), 965-994. https://doi.org/10.1007/s11004-017-9700-3. 
Paull, C. K., Talling, P. J., Maier, K. L., Parsons, D., Xu, J., Caress, D. W., ... \& Chaffey, M. (2018). Powerful turbidity currents driven by dense basal layers. Nature Communications, 9(1), 4114. https://doi.org/10.1038/s41467-018-06254-6.

Peakall, J., McCaffrey, B., \& Kneller, B. (2000). A process model for the evolution, morphology, and architecture of sinuous submarine channels. Journal of Sedimentary Research, 70(3), 434-448. https://doi.org/10.1306/2DC4091C-0E47-11D7-8643000102C1865D.

Pirmez, C., Beaubouef, R. T., Friedmann, S. J., \& Mohrig, D. C. (2000). Equilibrium profile and baselevel in submarine channels: examples from Late Pleistocene systems and implications for the architecture of deepwater reservoirs. In Global deep-water reservoirs: Gulf Coast Section SEPM Foundation 20th Annual Bob F. Perkins Research Conference (pp. 782-805). https://doi.org/10.5724/gcs.00.15.0782.

Pirmez, C., \& Imran, J. (2003). Reconstruction of turbidity currents in Amazon Channel. Marine and petroleum geology, 20(6-8), 823-849. https://doi.org/10.1016/j.marpetgeo.2003.03.005.

Posamentier, H., (2003). Depositional elements associated with a basin floor channel-levee system: case study from the Gulf of Mexico. Marine and Petroleum Geology 20, 677-690. https://doi.org/10.1016/j.marpetgeo.2003.01.002.

Pyrcz, M. J., Sech, R. P., Covault, J. A., Willis, B. J., Sylvester, Z., \& Sun, T. (2015). Stratigraphic rule-based reservoir modeling. Bulletin of Canadian Petroleum Geology, 63(4), 287-303. https://doi.org/10.2113/gscpgbull.63.4.287.

Reading, H. G., \& Richards, M. (1994). Turbidite systems in deep-water basin margins classified by grain size and feeder system. AAPG bulletin, 78(5), 792-822.

Samuel, A., Kneller, B., Raslan, S., Sharp, A., \& Parsons, C. (2003). Prolific deep-marine slope channels of the Nile Delta, Egypt. AAPG bulletin, 87(4), 541-560. https://doi.org/10.1306/1105021094.

Sauer, V. B., \& Turnipseed, D. P. (2010). Stage measurement at gaging stations (p. 45). US Department of the Interior, US Geological Survey.

Savitzky, A., \& Golay, M. J. (1964). Smoothing and differentiation of data by simplified least squares procedures. Analytical chemistry, 36(8), 1627-1639.

Shepard, F. P. (1965). Types of submarine valleys. AAPG Bulletin, 49(3), 304-310.

Shumaker, L., E., Jobe, Z., Johnstone, S., A., Pettinga, L., A., Cai, D., Moody, J., D. (2018). Controls on submarine channel-modifying processes identified through morphometric scaling relationships. Geosphere. https://doi.org/10.1130/GES01674.1.

Skene, K. I., Piper, D. J., \& Hill, P. S. (2002). Quantitative analysis of variations in depositional sequence thickness from submarine channel levees. Sedimentology, 49(6), 1411-1430. https://doi.org/10.1046/j.1365-3091.2002.00506.x.

Straub, K. M., Mohrig, D., McElroy, B., Buttles, J., \& Pirmez, C. (2008). Interactions between turbidity currents and topography in aggrading sinuous submarine channels: A laboratory study. GSA Bulletin, 120(3-4), 368-385. https://doi.org/10.1130/B25983.1.

Strong, N., \& Paola, C. (2008). Valleys that never were: time surfaces versus stratigraphic surfaces. Journal of Sedimentary Research, 78(8), 579-593. https://doi.org/10.2110/jsr.2008.059.

Sweet, W. V., \& Geratz, J. W. (2003). Bankfull hydraulic geometry relationships and recurrence intervals for North Carolina's coastal plain 1. Journal of the American Water Resources Association, 39(4), 861-871. https://doi.org/10.1111/j.1752-1688.2003.tb04411.x.

Sylvester, Z., Pirmez, C., \& Cantelli, A. (2011). A model of submarine channel-levee evolution based on channel trajectories: Implications for stratigraphic architecture. Marine and Petroleum Geology, 28(3), 716-727. https://doi.org/10.1016/j.marpetgeo.2010.05.012.

Sylvester, Z., \& Pirmez, C. (2017) Latitudinal changes in the morphology of submarine channels: reevaluating the evidence for the influence of the coriolis force. SEPM Special Publication, 108(2). http://dx.doi.org/10.2110/sepmsp.108.02.

Traer, M. M., Fildani, A., Fringer, O., McHargue, T., \& Hilley, G. E. (2018b). Turbidity current dynamics: 2. Simulating flow evolution toward equilibrium in idealized channels. Journal of Geophysical Research: Earth Surface, 123(3), 520-534. https://doi.org/10.1002/2017JF004202.

Tye, R. S. (2004). Geomorphology: An approach to determining subsurface reservoir dimensions. AAPG bulletin, 88(8), 1123-1147. https://doi.org/10.1306/02090403100. 
Weill, P., Lajeunesse, E., Devauchelle, O., Métiver, F., Limare, A., Chauveau, B., \& Mouazé, D. (2014). Experimental investigation on self-channelized erosive gravity currents. Journal of Sedimentary Research, 84(6), 487-498. https://doi.org/10.2110/jsr.2014.41

Weimer, P., \& Slatt, R. M. (2004). Petroleum systems of deepwater settings. Society of Exploration Geophysicists and European Association of Geoscientists and Engineers.

Wetzel, A. (1993). The transfer of river load to deep-sea fans: a quantitative approach. AAPG Bulletin, 77(10), 1679-1692.

Wiles, E., Green, A., Watkeys, M., \& Jokat, W. (2017). The Zambezi Channel: A new perspective on submarine channel evolution at low latitudes. Geomorphology, 286, 121-132. https://doi.org/10.1016/j.geomorph.2017.02.014.

Williams, G. P. (1978). Bank-full discharge of rivers. Water resources research, 14(6), 1141-1154. https://doi.org/10.1029/WR014i006p01141.

Williams, G. P. (1986). River meanders and channel size. Journal of hydrology, 88(1-2), 147-164. https://doi.org/10.1016/0022-1694(86)90202-7.

Wolman, M. G., \& Miller, J. P. (1960). Magnitude and frequency of forces in geomorphic processes. The Journal of Geology, 68(1), 54-74. https://doi.org/10.1086/626637.

Wynn, R. B., Cronin, B. T., \& Peakall, J. (2007). Sinuous deep-water channels: Genesis, geometry and architecture. Marine and Petroleum Geology, 24(6-9), 341-387. 10.1016/j.marpetgeo.2007.06.001. 